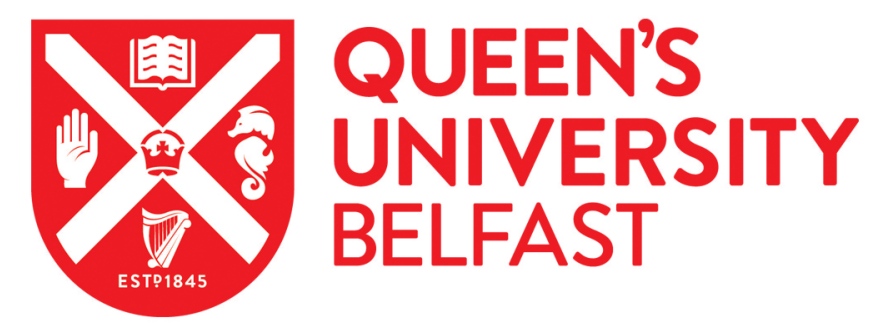

\title{
Gremlin1 preferentially binds to Bone Morphogenetic Protein-2 (BMP- 2) and BMP-4 over BMP-7
}

Church, R. H., Krishnakumar, A., Urbanek, A., Geschwinder, S., Meneely, J., Bianchi, A., Basta, B., Monaghan, S., Elliott, C., Stromstedt, M., Ferguson, N., Martin, F., \& Brazil, D. P. (2015). Gremlin1 preferentially binds to Bone Morphogenetic Protein-2 (BMP-2) and BMP-4 over BMP-7. Biochemical Journal, 466(1), 55-68. https://doi.org/10.1042/BJ20140771

Published in:

Biochemical Journal

Document Version:

Peer reviewed version

Queen's University Belfast - Research Portal:

Link to publication record in Queen's University Belfast Research Portal

Publisher rights

The final version of record is available at http://www.biochemj.org/bj/imps/abs/BJ20140771.htm

\section{General rights}

Copyright for the publications made accessible via the Queen's University Belfast Research Portal is retained by the author(s) and / or other copyright owners and it is a condition of accessing these publications that users recognise and abide by the legal requirements associated with these rights.

Take down policy

The Research Portal is Queen's institutional repository that provides access to Queen's research output. Every effort has been made to ensure that content in the Research Portal does not infringe any person's rights, or applicable UK laws. If you discover content in the Research Portal that you believe breaches copyright or violates any law, please contact openaccess@qub.ac.uk. 
Gremlin1 preferentially binds to Bone Morphogenetic Protein-2 (BMP-2) and BMP-4 over BMP-7

Rachel H. Church*, Arjun Krishnakumar*, Annika Urbanek §, Stefan Geschwindner †, Julie Meneely $\ddagger$, Alessandro Bianchi $\S$, Barbro Basta $\uparrow$, Sean Monaghan*, Christopher Elliot $\ddagger$, Maria Stromstedt $\uparrow$, Neil Ferguson $\S$, Finian Martin $\S$ and Derek P. Brazil*

* From the Centre for Experimental Medicine, Queen's University Belfast, Northern Ireland, UK. † Astra Zeneca, Mölndal, Gothenburg, Sweden.

$\ddagger$ Institute for Global Food Security, School of Biological Sciences, Queen’s University Belfast, Northern Ireland, UK.

$\S$ UCD Conway Institute, University College Dublin, Belfield, Dublin 4, Ireland

Running Title: Differential Gremlin1 binding to Bone Morphogenetic Proteins

To whom correspondence should be addressed: Derek P. Brazil, Centre for Experimental Medicine, ICS-A, Grosvenor Road, Belfast BT12 6BA, Northern Ireland. Tel: 0044-28-9063-2572; Fax: 004428-9063-2699; E-mail: d.brazil@qub.ac.uk

Keywords: Gremlin; bone morphogenetic protein (BMP); Smad; kidney: epithelial cell; surface plasmon resonance (SPR), fibrosis. 


\begin{abstract}
Gremlin (Grem1) is a member of the DAN family of secreted bone morphogenetic protein (BMP) antagonists. Bone morphogenetic protein-7 (BMP-7) mediates protective effects during renal fibrosisassociated with diabetes and other renal diseases. The pathogenic mechanism of Grem1 during DN has been suggested to be binding and inhibition of BMP-7. However, the precise interactions between Grem1, BMP-7 and other BMPs have not been accurately defined. Here we show the affinity of Grem1 for BMP-7 is lower than that of BMP-2 and BMP-4, using a combination of surface plasmon resonance and cell culture techniques. Using kidney proximal tubule cells and HEK-293 cell Smad1/5/8 phosphorylation and BMP-dependent gene expression as readout, Grem1 consistently demonstrated a higher affinity for BMP-2>4>7. Cell-associated Grem1 did not inhibit BMP-2 or BMP-4 mediated signalling, suggesting that Grem1-BMP-2 binding occurred in solution, preventing BMP receptor activation. These data suggest that Grem1 preferentially binds to BMP-2 and this may be the dominant complex in a disease situation where levels of Grem1 and BMPs are elevated.
\end{abstract}

\title{
Summary Statement
}

Gremlin1 has a distinct preference for which bone morphogenetic protein it binds to in kidney epithelial cells. Grem1-BMP-2 complexes are favoured over other BMPs, and this may play an important role in fibrotic kidney disease.

\section{Introduction}

Bone morphogenetic proteins (BMPs) are glycosylated extracellular matrix associated members of the transforming growth factor beta (TGF- $\beta$ ) super-family [1]. BMPs were originally identified for their ability to induce bone formation in vivo via osteoblast differentiation [2, 3]. BMPs have a key function in morphogenesis, general organogenesis, cartilage and limb formation, as well as cell proliferation, differentiation and apoptosis [1, 3-5]. BMPs have a critical role in kidney development as evidenced by data showing that BMP-7 null mice are postnatal lethal due to various developmental abnormalities including kidney agenesis [6,7]. Whereas BMP-4 has been shown to contribute to renal fibrosis, conflicting evidence exists for the pro- or anti-fibrotic role of BMP-2 in this process [8-11]. BMP-7 is thought of as anti-fibrotic, and has been the focus of many groups who demonstrated its anti-fibrotic activity in models of diabetic nephropathy and other kidney fibrotic diseases [5, 12-17]. To date, however, efforts to translate these data into BMP-7-centred treatment of fibrosis have been rather slow to develop $[18,19]$

Canonical BMPs signalling involves the Smad pathway, where BMP dimers bind to type I and type II BMP receptors leading to the formation of a hexameric complex, triggering receptor phosphorylation. This leads to phosphorylation of R-Smads (Smad1/5/8) and complex formation with co-Smad4 which translocates to the nucleus to regulate BMP target gene expression [1, 2]. BMP target genes include inhibitor of differentiation (Id 1-3) genes and inhibitory Smad 6 [1, 2]. BMP signalling is regulated on multiple levels: intracellularly by inhibitory Smads (Smad 6,7), miRNAs, methylation and extracellularly by pseudoreceptors such as BAMBI and BMP antagonists including Gremlin (Grem1), Nogginand twisted gastrulation 1 (Twsg 1) [1, 2, 20].

Grem1 is an 184 amino acid $(25 \mathrm{kDa})$ cysteine knot superfamily protein that exists in both secreted and cell associated forms [21]. Grem1 exerts an inhibitory effect by directly binding to BMP dimers, preventing their interaction with BMP receptors, as well as blocking BMP secretion and increasing extracellular BMP endocytosis [1, 22, 23]. Typically, homozygous Grem1 deletion in mice leads to neonatal lethality due to development abnormalities including bilateral agenesis of the kidneys, lung defects and limb malformations [24, 25]. However, recently it has been shown that some grem1 null mice survive when generated on a mixed genetic background (C57BL/6/FVB, 27). Grem1 null mice were smaller, with decreased weight and a shortened femoral length [26]. The lack of kidney development in grem1-/- mice was rescued by deletion of one allele of BMP-4 [27]. 
Conversely, deletion of both alleles of BMP-7 rescued the ureteric branching defect but not the nephrogenesis defect [28], highlighting the critical nature of the balance between Grem1 levels and individual BMPs during kidney development.Grem1 is induced in response to high glucose in human mesangial cells, human proximal tubule epithelial cells and podocytes [29-33]. Grem1 is implicated in fibrotic diseases including diabetic nephropathy [32, 33], chronic allograft nephropathy [34], immune glomerulonephritis [35] and human idiopathic pulmonary fibrosis [36]. Heterozygous greml deletion in mice protects against early DN-like changes in a streptozotocin (STZ) model of diabetes [32]. Additionally, siRNA silencing of Grem1 has shown beneficial effects in an STZ mouse model through maintaining BMP-7 activity and reducing DN-like characteristics [37]. The increased level of Grem1 in fibrotic kidney disease is thought to contribute to pathogenesis via inappropriate inhibition of BMP signalling.

The aim of this study was to characterise Grem1 binding to BMP-7 and other BMPs. Our data suggest that Grem1 has a low affinity for BMP-7, and preferentially binds to BMP-2 using kidney epithelial cells as a model. Our results will help to refine our model of how Grem1 contributes to kidney fibrosis during diabetes and other diseases. 


\title{
Experimental Procedures
}

\author{
Detection of rhGrem1, BMP-2, BMP-4 and BMP-7 by Coomassie Violet staining and Western \\ blot. \\ For Coomassie Violet staining, recombinant human (rh) Grem1, BMP-2, BMP-4, BMP-6 and BMP-7 \\ (R\&D Systems, Minneapolis, USA) samples were prepared at $0.5 \mu \mathrm{g}$ and $1.0 \mu \mathrm{g}$ via dilution with the \\ appropriate vehicle (PBS (Grem1) or $4 \mathrm{mM} \mathrm{HCl}$ (BMPs)) and added to an equal volume of $2 \mathrm{x}$ \\ Laemmli buffer without supplemental reducing agent. Samples were separated without boiling on 10 \\ $\%(\mathrm{v} / \mathrm{v})$ SDS-PAGE and stained with Coomassie Violet solution
}

For Western blotting, recombinant human (rh) Grem1, BMP-2, BMP-4, BMP-6and BMP-7 samples were prepared at $100 \mathrm{ng}$ and $500 \mathrm{ng}$ via dilution with the appropriate vehicle (PBS (Grem1) or $4 \mathrm{mM}$ $\mathrm{HCl}$ (BMPs)) and added to an equal volume of $2 \mathrm{x}$ Laemmli buffer in the absence of reducing agent. Samples were separated without boiling on $10 \%$ (v/v) SDS-PAGE and probed via Western blotting using antibodies reactive to Grem1, BMP-2, BMP-4 or BMP-7 (R\&D Systems, Minneapolis, USA).

\section{Surface Plasmon Resonance (SPR)}

Recombinant human BMP-2, 4, 6, 7 (R\&D Systems, Minneapolis, USA) were immobilised onto individual flow channels of Xantec SPR Sensorchip HLC 30m (XanTec bioanalytics GmbH, Germany) via an amine coupling procedure. The surface of the Xantec SPR Sensorchip HLC 30m was pre-equilibrated with borate elution buffer ( $30 \mu \mathrm{L}$; flow rate: $10 \mu \mathrm{L} / \mathrm{min}$ ) (XanTec bioanalytics $\mathrm{GmbH}$, Germany) before being activated with a 1:1 mixture of $0.4 \mathrm{M}$ 1-ethyl-3-(3dimethylaminopropyl)carbodimide (EDC) and $0.1 \mathrm{M}$ N-hydroxysuccinimide (NHS) $(50 \mu \mathrm{L}$; flow rate $10 \mu \mathrm{L} / \mathrm{min}$ ) (GE Healthcare, Uppsala, Sweden). rhBMPs were reconstituted at $100 \mu \mathrm{g} / \mathrm{ml}$ in $10 \mathrm{mM}$ sodium acetate buffer pH 5.5 (GE Healthcare, Uppsala, Sweden) and diluted 1:100 with the same buffer. Twenty $\mu \mathrm{L}$ rhBMPs were injected at a flow rate of $10 \mu \mathrm{L} / \mathrm{min}$ until a response of approximately $500 \mathrm{RU}$ was obtained. Remaining reactive sites on the flow channels were deactivated with $1 \mathrm{M}$ ethanolamine $\mathrm{pH} 8.5(70 \mu \mathrm{L}$; flow rate: $10 \mu \mathrm{L} / \mathrm{min})$.

Recombinant hGreml was reconstituted at $200 \mu \mathrm{g} / \mathrm{ml}(10 \mu \mathrm{M})$ in running buffer $(2 \mathrm{x}$ PBS-20 mM phosphate, $5.4 \mathrm{mM} \mathrm{KCl}, 274 \mathrm{nM} \mathrm{NaCl}$ and $0.05 \%$ (v/v) Tween-20). Increasing concentrations of rhGrem1 were injected in the running buffer for $120 \mathrm{~s}(60 \mu \mathrm{L}$ at a flow rate of $30 \mu \mathrm{L} / \mathrm{min}$; dissociation time: $480 \mathrm{~s}$. Regeneration injections were performed with $10 \mathrm{mM}$ glycine $\mathrm{HCl} \mathrm{pH} 1.5$ after each rhGrem1 injection $(20 \mu \mathrm{L}$, flow rate $30 \mu \mathrm{L} / \mathrm{min})$. Sensorgrams were subjected to double referencing with subtraction of their respective control sensorgrams and blank injections. Experiments were performed on a Biacore 3000 instrument.

\section{Size exclusion chromatography}

Size exclusion chromatography (SEC) was performed at $20{ }^{\circ} \mathrm{C}$ with a Shimadzu high-performance liquid chromatography (HPLC) apparatus connected to Wyatt Dawn Heleos II light scattering and Optilab rEX instruments (Wyatt Technology, CA). SEC was performed in 2 x PBS using a $15 \mathrm{~mL}$ analytical KW-803 SEC column (Shodex, Japan) that was housed inside a thermostatted column oven. Five $\mu \mathrm{L}$ protein samples were injected at protein concentrations of $\sim 50 \mu \mathrm{M}$.

\section{Microscale thermophoresis}

Protein samples were labelled for microscale thermophoresis (MST) measurements using an amine reactive coupling reaction (specifically a NT-647 N-hydroxysuccinimide protein-labelling kit, NanoTemper Technologies, Germany). Tween 20 was added to the $2 \times$ PBS buffer to a final concentration of $0.05 \%(\mathrm{v} / \mathrm{v})$ to reduce protein adsorption to plasticware and the side-walls of the disposable glass capillaries used for MST measurements. One hundred nM labelled BMP-4 was titrated with unlabeled Grem1 using a series of 1:2 serial dilutions (up to a maximum concentration of $1 \mu \mathrm{M}$ Grem). Four $\mu \mathrm{L}$ of each sample was then aspirated into hydrophilic capillaries, and MST measurements performed at $22{ }^{\circ} \mathrm{C}$ using a Monolith NT.115 (NanoTemper Technologies, Germany). The light-emitting diode that excites labelled protein fluorescence was set to $30 \%$, and a heating laser power of $40 \%$ was used to induce the temperature gradient that MST measurements employ. Laser on and off times were set to $30 \mathrm{~s}$ and $5 \mathrm{~s}$, respectively. 


\section{Cell culture}

Human kidney proximal tubule epithelial cells (HK-2) were cultured as previously described [33]. HEK293T cells were grown in DMEM media containing $10 \%$ (v/v) foetal calf serum and $100 \mu \mathrm{g} / \mathrm{ml}$ primocin (Invivogen, UK).

\section{Cell treatments-Western blotting}

For BMP stimulation of Smad1/5/8 phosphorylation, HK-2 and HEK293 cells were plated on $60 \mathrm{~mm}$ plates. At $70 \%$ confluence, cells were washed with 1 x PBS and treated with HK-2 complete medium supplemented with vehicle $(4 \mathrm{mM} \mathrm{HCl})$ or increasing concentrations of rhBMP-2, rhBMP-4 (0.5-10 $\mathrm{ng} / \mathrm{ml}$ ) or rhBMP-7 (5-50 ng/ml) (R\&D Systems, Minneapolis, USA) for $60 \mathrm{~min}$. For rhGrem1 inhibition experiments, HK-2 cells were treated with complete medium supplemented with vehicle (4 $\mathrm{mM} \mathrm{HCl}$ ), $5 \mathrm{ng} / \mathrm{ml} \mathrm{rhBMP-2,} 5 \mathrm{ng} / \mathrm{ml}$ rhBMP-4 or $20 \mathrm{ng} / \mathrm{ml} \mathrm{rhBMP}-7$ in the absence or presence of increasing concentrations of rhGrem1 $(5-400 \mathrm{ng} / \mathrm{ml})$ (R\&D Systems, Minneapolis, USA) for $60 \mathrm{~min}$. rhGrem1 and BMP proteins were co-incubated in complete medium at $37{ }^{\circ} \mathrm{C}$ for $15 \mathrm{~min}$ prior to adding to cells.To assess the effect of cell associated Grem1, HK-2 cells were pre-treated with HK-2 complete medium supplemented with vehicle (PBS), $25 \mathrm{ng} / \mathrm{ml}$ Grem1 (for BMP-2) or $200 \mathrm{ng} / \mathrm{ml}$ Grem1 (for BMP-4) for 60 min. The medium was removed and replaced with fresh HK-2 complete medium supplemented with vehicle $(4 \mathrm{mM} \mathrm{HCl}), 5 \mathrm{ng} / \mathrm{ml}$ BMP-2 or $5 \mathrm{ng} / \mathrm{ml} \mathrm{BMP-2}$ plus $25 \mathrm{ng} / \mathrm{ml}$ rhGrem1. A similar approach was employed for BMP-4, with $5 \mathrm{ng} / \mathrm{ml} \mathrm{BMP-4}$ and $200 \mathrm{ng} / \mathrm{ml} \mathrm{rhGrem} 1$ utilized.

\section{Construction of pcDNA3.1/myc-hisA-hGrem1 plasmid}

A DNA fragment containing the entire coding sequence for Grem1 was amplified by RT-PCR on cDNA from HK-2 cells using forward primer $5^{\prime}$ GACAGTGAATTCATGAGCCGCACAGCCTACACG-3' and reverse primer 3'GGATTTTCTAGAATCCAAATCGATGGATATGCA-5' and RedTaq ${ }^{\circledR}$ DNA polymerase at an annealing temperature of $55{ }^{\circ} \mathrm{C}$. The fragment was restriction digested using EcoR1 and Xba 1 (Fermentas, UK) to create sticky ends. The fragment was ligated using T4 DNA ligase (Life Technologies, UK) into pcDNA ${ }^{\mathrm{TM}} 3.1 /$ myc-hisA (Invitrogen, UK) that was cut with EcoR1 and Xba1. The ligated product was used to transform competent XL-1 blue E.coli (Agilent Technologies) which were then plated onto LB-ampicillin plates. Positive colonies were identified by PCR, and pcDNA3.1/myc-hisA-hGrem1 plasmid was extracted from cells using Pure Yield ${ }^{\mathrm{TM}}$ Plasmid Maxiprep system (Promega, UK). All final plasmid DNA was validated by Sanger sequencing.

Transfection and immunocytochemistry of HEK293 cells

HEK293 cells were grown on glass coverslips were transfected with empty plasmid ( $p c D N A 3.1)$ or plasmid containing full-length human Grem1 cDNA ( $p c D N A 3.1-h$ Greml) using Lipofectamine ${ }^{\mathrm{TM}}$ 2000 (Invitrogen UK). Forty eight hours post-transfection, cells were incubated in serum free DMEM for $4 \mathrm{~h}$ and treated with vehicle $(4 \mathrm{mM} \mathrm{HCl})$ or $5 \mathrm{ng} / \mathrm{ml} \mathrm{BMP}-2$ for $60 \mathrm{~min}$. Cells were fixed in $4 \%$ PFA, permeabilised with $0.1 \%$ Triton-X, blocked in $1 \%$ BSA and stained with $\alpha$-myc (9E10) and pSMAD1/5 (Cell Signalling) primary antibodies. Anti-mouse TRITC and anti-rabbit FITC secondary antibodies were used for detection, together with DAPI (blue) to visualise the nuclei.

Conditioned medium from empty vector and pcDNA3.1-hGrem1 transfected cells of various dilutions was added to fresh, non-transfected HEK293 cells in the presence of $5 \mathrm{ng} / \mathrm{ml} \mathrm{rhBMP}-2,4$ or 7 for 60 min. Cells were lysed in supplemented RIPA buffer and Western blotting for phospho-Smad1/5/8 and $\beta$-actin was carried out exactly as described $[38,39]$. Densitometry analysis was performed using Image $\mathbf{J}$ software (http://rsbweb.nih.gov/ij/) and pSmad1/5/8 band intensities were expressed as a ratio of $\beta$-actin loading control intensity for each sample.

\section{Real-time quantitative PCR}

For BMP stimulation and Grem1 inhibition of BMP gene responses, HK-2 cells were plated on $60 \mathrm{~mm}$ plates. At $70 \%$ confluence, cells were washed with 1 x PBS and treated with HK-2 complete medium supplemented with vehicle ( $4 \mathrm{mM} \mathrm{HCl}), 10 \mathrm{ng} / \mathrm{ml} \mathrm{rhBMP-2,} 10 \mathrm{ng} / \mathrm{ml} \mathrm{rhBMP}-4$, or $20 \mathrm{ng} / \mathrm{ml} \mathrm{rhBMP}-$ 
7 in the absence or presence of increasing concentrations of rhGrem1 $(25-400 \mathrm{ng} / \mathrm{ml})$ for $2 \mathrm{~h}$. Recombinant proteins were co-incubated in complete medium at $37{ }^{\circ} \mathrm{C}$ for $15 \mathrm{~min}$ prior to adding to the cells. RNA was extracted using an RNeasy RNA extraction kit according to the manufacturers protocol (Qiagen). Total RNA $(1 \mu \mathrm{g})$ was reverse transcribed and Taqman PCR was performed using specific Taqman probes from Roche Applied Science for Id1 (Assay ID: 104631), Smad6 (Assay ID: 104698) or Grem1 (Assay ID: 105548). Levels of ALK receptor expression were measured in HK-2 and HEK293 cells using Roche Taqman probes for ACVR1 (ALK 2) (Assay Id: 104525), BMPR1A (ALK 3) (Assay Id: 104581) and BMPR1B (ALK 6) (Assay Id: 104584). All analysis was carried out using the $\Delta \Delta$ comparative threshold $(\mathrm{Ct})$ method and normalized to an average of 18S (Assay ID: 104092) and $\beta$-actin (Assay ID: 101125) levels. Real-time PCR was carried out on a Roche LightCycler 480.

\section{Statistical analysis}

All experiments were carried out a minimum of three times in duplicate, and statistically significant differences were detected using Student's unpaired t-test or one-way ANOVA with Bonferroni's Multiple Comparison Test using GraphPad Prism. P-values $<0.05$ were considered significant. 


\section{Results}

\section{Analysis of commercially available recombinant Grem1 and BMPs}

We first assessed the fidelity of commercial sources of recombinant Grem1 and BMPs, which are widely used in the field. Thus, recombinant human (rh) Grem1 and BMP-2, -4, -6 and -7 samples (all from R\&D Systems) were prepared and subjected to $10 \%$ SDS-PAGE in the absence of reducing agents and boiling (i.e. non-reducing SDS-PAGE). Protein bands were visualised by both Coomassie Violet staining (Fig. 1a) or Western blotting (Fig. 1b-f). Table 1 summarises the predicted molecular weights of the recombinant proteins versus those detected by SDS-PAGE under reducing and nonreducing conditions.

Two predominant bands for rhGrem1 were detected. One had a gel mobility consistent with a mass of 25-27 kDa, close to the expected mass for a Grem1 monomer ( 21 kDa), whereas the other had a mass of $\sim 14 \mathrm{kDa}$. Since both species reacted strongly with antibodies specific to rhGrem1, we attributed the lower mass species to a Grem1 breakdown product. This lower mass species could also be a glycosylated Grem1 variant with an idiosynchratic gel mobility. Notably, full length rhGrem1 was present at significantly higher abundance than the minor breakdown product.

We next used size exclusion chromatography in conjunction with multi angle light scattering (SECMALS) to further analyse rhGrem1. SEC-MALS is a powerful tool for directly measuring the mass, purity and concentration of biomolecules in solution. Using this approach, we observed just two species eluting from the high resolution SEC column, with relative elution volumes of $\sim 11.9 \mathrm{ml}$ and $\sim 12.3 \mathrm{ml}$, with relative abundances of $\sim 10 \%$ and $\sim 90 \%$, respectively, based on the integrated UV peak areas (Fig. 2c). The elution profile is consistent with the results obtained using SDS-PAGE and Western blotting, with the most abundant species (native monomeric rGrem1) eluting later from the SEC column than the breakdown product/glycosylated rhGrem1 (presumably due to it being either unfolded or non-globular). Unfortunately, the low molecular weight of rhGrem1 combined with the low protein concentrations available meant that rGrem1 did not scatter light sufficient to determine its molar mass using MALS. Non-reducing SDS-PAGE and Western blotting showed that monomeric forms of BMP-2 and BMP-7 were the most abundant in commercial, recombinant sources (Fig. 1a, c, e). In contrast, higher order oligomers were observed for BMP-4 and BMP-6, although these were also significantly less abundant than the monomeric forms (Fig. 1d, f). Most BMPs examined, however, yielded only a single species when examined using silver stained, reducing SDS-PAGE (Suppl. Fig. 1). This supports the view that the complexity observed on non-reducing SDS-PAGE is likely to be associated with oligomeric forms of BMPs refractory to denaturation (in non-reducing SDS-PAGE), as opposed to higher molecular weight contaminants or unprocessed BMP species. The exception to this was BMP-6, which did not silver stain in our experiments, despite staining with Coomassie Blue (Fig. 1a, Suppl. Fig. 1a).

SEC-MALS analysis showed that rhBMP-2 yielded only a single, symmetrical elution peak in PBS buffer (Fig. 2d). These results were consistent with rhBMP-2 being homogeneous, in agreement with the results obtained using SDS-PAGE and Western blotting. As per rhGrem1, the protein concentrations used were too low to obtain a molar mass for BMP-2 using SEC-MALS. BMP-4, BMP-6 and BMP-7 reproducibly failed to elute from SEC columns, precluding any objective assessment of their solution oligomeric state (data not shown).

\section{Recombinant Gremlin1 binds BMPs with different affinities}

Real-time surface plasmon resonance (SPR) was used to characterise the binding of recombinant human BMPs to rhGrem1. Initially, rhGrem1 was attached as "bait" to BIAcore Xantec sensorchips using amine-reactive coupling, and a series of rhBMPs were then used as analytes to probe for binding events. However, little or no BMP binding was detected, suggesting that the coupling of rhGrem1 to the BIAcore surface impinged on the binding interface required for BMP binding (data not shown). Thus, the reverse approach was then implemented and BMP-2, 4, 6, 7 were individually coupled to individual flow cells on the BIAcore sensor chip surface. This approach had merit for two reasons: (i) to keep rGrem1 active (which is not the case when it was coupled to an SPR chip, see above); (ii) all BMPs will see the same rhGrem1 preparation, including the $10 \%$ low abundance Grem1 species observed by SEC-MALS and Western blot discussed above (Fig. 1b). 
Increasing concentrations of rhGrem1 (ranging from $10 \mathrm{nM}-3 \mu \mathrm{M}$ ) were injected onto the SPR chip and the relative binding in response units (RU) was measured for each immobilised BMP. This approach gave high quality data, with excellent signal to noise ratios and yielded a set of concentration dependent binding kinetics (BMP-7 shown as example, Fig. 2). At the lower Grem1 concentrations examined (10-300 nM), there was clear evidence for association kinetics that typically report on ligand binding, and from which on-rates $\left(k_{\mathrm{ON}}\right)$ are determined. Conversely, no convincing dissociation phases were observed after rhGrem1 injections $(10-300 \mathrm{nM})$ were ceased. This was problematic as it is these dissociation phases that are typically used to determine off-rates, and ultimately $\mathrm{Kd}$ values. This phenomenon could be due to very tight binding between BMPs and rhGrem1, or irreversible, nonspecific binding of rhGrem1 to the SPR chip surface (i.e. in the absence of immobilised BMPs). However, no irreversible binding was observed in 'empty' reference channels (i.e. no immobilised BMPs were present). Clear dissociation phases were evident, however, for each BMP when higher concentrations of rhGrem1 ( $\geq 1 \mu \mathrm{M})$ were injected onto the SPR chip. We believe that this additional phase, which was observed only at higher concentrations of rhGrem1, most likely reflects the reversible binding of rhGrem 1 to BMPs.

The SPR sensorgrams were analysed in two different ways: (i) fitting the association and dissociation kinetics to a 1:1 Langmuir analysis, which assumes a single binding site (Table 2), (ii) assuming a bivalent analyte, where each rhGrem1 can bind multiple BMPs (which seems possible, as Grem1 has been reported to be a functional dimer). We specifically fitted only the $3 \mu \mathrm{M}$ rhGrem1 injections (which exhibited reversible association-dissociation kinetics), although comparable $\mathrm{Kd}$ values were obtained for the $1 \mu \mathrm{M}$ rhGrem1 datasets (data not shown). For each BMP, the dissociation phases fitted well to the 1:1 Langmuir function (Table 2). The association phases fitted less well, although well within what is normally accepted for publication quality SPR data. Using this approach, the rank order of interaction affinity, from tightest binding to the weakest, was BMP4=BMP2>BMP6>BMP7 (Table 2). Fitting the data to a bivalent analyte function gave excellent fits, and yielded a rank order of binding affinity, from tightest binding to weakest, of BMP4 >BMP2 $>$ BMP6>BMP7 for the tighter of the two modelled binding events (although their absolute magnitude varied from those calculated using the Langmuir analysis, Suppl. Table 1). In our opinion, the weaker of the two binding sites modelled using the bivalent analyte analysis did not yield physically sensible parameters, and the high quality fits obtained was merely a consequence of employing a fitting procedure that had more variables than the Langmuir analyses.

We next employed microscale thermophoresis to try and obtain objective independent validation of the binding affinities for each BMP for rhGrem1. Since our SPR experiments showed that coupling rhGrem1 to SPR chips inactivated it, we elected to label the BMPs with a red dye (using amine reactive coupling, as per our SPR experiments). Using this approach, we found that we could successfully label BMP4 with the red dye. By contrast, it was not possible to obtain labelled BMP-2, BMP-6 and BMP-7, as these proteins did not elute from to the small SEC columns used to separate labelled proteins from unincorporated dye. This experiment again demonstrate the challenges of studying BMP interactions in vitro, as similar issues occurred in our SEC-MALS studies of BMPs (discussed above).

High quality binding curves were obtained when labelled BMP-4 was titrated with rhGrem1 (Fig. $2 \mathrm{e})$. The apparent $\mathrm{Kd}$ of this curve $(\leq 50 \mathrm{nM})$ agreed fairly well with the apparent Kd determined using SPR and the Langmuir analysis $(\mathrm{Kd} \sim 28 \mathrm{nM})$. By contrast, the Kd determined for BMP-4rhGrem 1 disagreed with the value obtained using a bivalent analyte analysis of the SPR data $(\mathrm{Kd} \sim 0.4$ $\mathrm{nM}$ ). Based on this benchmarking of the SPR data, and the problems seen with irreversible binding of BMPs to silica and polymer based SEC columns, we believe that our SPR data were best described by the 1:1 Langmuir analysis, and ignoring the apparently irreversible binding seen at low rGrem1 concentrations (10-300nM). Irrespective of these issues, in each case (i.e. Langmuir analysis or bivalent analyte), the weakest binder to rhGrem1 was BMP7, with BMP2 and BMP4 having considerably higher affinity for rhGrem1. 
Differential BMP-mediated pSmad1/5/8 signalling and Gremlin1 inhibition in kidney epithelial cells BMP binding to heterotetrameric type I/II receptor complexes leads to Smad1/5/8 phosphorylation, dimerization with co-Smad4, nuclear translocation and transcriptional activation [2]. To validate the SPR and MST protein interaction data in a cell culture system, human kidney proximal tubule epithelial cells (HK-2) were incubated with increasing concentrations of rhBMPs (BMP-2; $0.5 \mathrm{ng} / \mathrm{ml}$ $10 \mathrm{ng} / \mathrm{ml},(39-790 \mathrm{pM})$, BMP-4; $0.5 \mathrm{ng} / \mathrm{ml}-10 \mathrm{ng} / \mathrm{ml}$, (39-780 pM) or BMP-7; 5-50 ng/ml (325 pM$3.25 \mathrm{nM}$ )). Robust Smad1/5/8 phosphorylation was seen in response to BMP-2 at $0.5 \mathrm{ng} / \mathrm{ml}$ (Fig. 3a) and BMP-4 at 1-2 ng/ml (Fig. 3b). In contrast, higher concentrations of BMP-7 (> $10 \mathrm{ng} / \mathrm{ml}$ ) were required to trigger a robust pSmad1/5/8 response in these cells (Fig. 3c). BMP-2, 4 and 7 have been reported to utilise similar BMP receptor complexes, with signalling transmitted via BMPRII/Alk3/6 heterotetramers for all 3 BMPs [40]. One potential difference for the reduced response to BMP-7 may be the ability of BMP-7 to specifically engage with Alk2 type I receptors [41, 42]. ACVR1/ALK2 and BMPRIA/ALK3 were the predominant isoforms detected in HK-2 (and HEK293) cells, with levels of ALK6 lowest in both cases (Fig. 3d). Thus, the absence of ALK2 receptors cannot explain the lower efficacy of BMP-7 in HK-2 cells.

Co-incubation of BMP-2 $(5 \mathrm{ng} / \mathrm{ml}, 395 \mathrm{pM})$ with $25 \mathrm{ng} / \mathrm{ml}$ Grem1 (1.33 nM) completely inhibited BMP-2 mediated Smad1/5/8 phosphorylation (Fig. 4a, b). In contrast, inhibition of BMP-4 mediated Smad1/5/8 phosphorylation was not detected until $100 \mathrm{ng} / \mathrm{ml}$ Grem1 (5.3 nM) was used (Fig. 4c, d). BMP-7 (20 ng/ml, $1.3 \mathrm{nM})$ triggered a strong increase in Smad1/5/8 phosphorylation, but this was not inhibited by coincubation with Grem1 up to $400 \mathrm{ng} / \mathrm{ml}(21.2 \mathrm{nM})$ (Fig. 4e, f). These data demonstrate that the potency of BMP-2 and 4 canonical signalling exceeds that of BMP-7 in HK-2 cells, and that rhGrem1 inhibits BMP-2>4>7 when endogenous BMP type I/II receptor activation is measured using pSmad $1 / 5 / 8$ as a readout. BMP signalling is transmitted via pSmad1/5/8 dimer formation with Smad4 which translocates to the nucleus and is recruited to transcriptional complexes on a defined set of BMP-responsive promoters of genes such as Id1-3 and Smad6 [1]. We wished to confirm that increased pSmad1/5/8 levels in response to BMP treatment corresponded to bona fide changes in BMP-mediated gene expression. Incubation of HK-2 cells with BMP-2 and 4 (10 ng/ml), and BMP-7 $(20 \mathrm{ng} / \mathrm{ml})$ induced a significant increase in Id1 and Smad6 mRNA (Fig. 5), consistent with increased pSmad1/5/8 phosphorylation (Fig. 4a). For BMP-2, this transcriptional response was inhibited by rhGrem1 in a concentration-dependent manner, with 50\% inhibition seen with $25 \mathrm{ng} / \mathrm{ml} \mathrm{Grem} 1$ (Fig. 5a, d). Higher amounts of Grem1 were required to inhibit BMP-4 mediated gene transcription which was only seen with $200 \mathrm{ng} / \mathrm{ml}$ Grem1 (Fig. 5b, e). Weak inhibition of BMP-7 stimulated

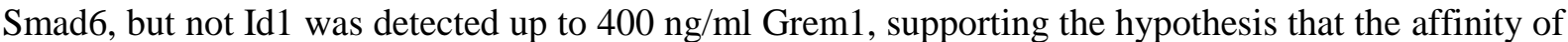
Grem1 for BMP-7 homodimers is lower than for BMP-2 (Fig. 5c, f). These data highlight that Grem1 binding to BMPs prevents receptor-mediated activation of BMP gene targets, and that the rank order of affinity of BMP-2>4>7 is consistent with data obtained when endogenous BMP gene targets are quantified.

Overexpression of human Gremlin1 inhibits BMP signalling in HEK293 cells

Given the critical role of Grem1 posttranslational processing and glycosylation in its function [43], the ability of Grem1 expression to inhibit BMP action when expressed in mammalian cells was then assessed. After optimization, a protocol was developed whereby $>80 \%$ transfection efficiency was routinely obtained in HEK293 cells using pcDNA3.1A containing the human Grem1 cDNA (Fig. 6). Gremlin expression was detected both intracellularly (Fig. 6a) and also in the cell-cell junctions and extracellular space (Suppl. Fig. 3). Treatment of HEK293 cells with BMP-2 increased Smad1/5 phosphorylation (Fig. 6a, top right panels) and transfection with myc-hGrem1 abolished this phosphorylation (Fig. 6a, bottom right panels). A similar profile was observed when transfected cells were treated BMP-4 (data not shown). These data suggest that the transfection of cells with fulllength human Grem1 leads to the production and secretion of hGrem1 from HEK293 cells, where it binds to the recombinant BMPs preventing receptor activation. Consistently, Grem1 protein was detected when the conditioned medium from Grem1-transfected cells was analysed (Fig. 6b).

To further interrogate the relative affinity of secreted, processed human recombinant Grem1 for BMP2, 4 and 7, conditioned medium from hGrem1-transfected cells was added to non-transfected HEK293 cells in the presence of rhBMP-2, 4 or 7 (Fig. 7). "Neat" conditioned medium from Grem1-transfected HEK293 cells completely inhibited pSmad1/5/8 phosphorylation in response to BMP-2 and 4, but not BMP-7 (Fig. 7, "100 \%"). Serial dilution of this conditioned medium demonstrated that recovery of 
BMP-2 mediated Smad1/5/8 phosphorylation only occurred after 3 sequential dilutions $(12.5 \%$ medium, Fig. 7a, b). In contrast, Smad1/5/8 phosphorylation was detected in BMP-4 stimulated cells when the conditioned medium was diluted 1:4 (25\%, Fig. 7a, c). Consistent with the fact that $100 \%$ conditioned medium modestly inhibited BMP-7-mediated Smad1/5/8 phosphorylation, no further changes were seen with sequential dilution (Fig. 7a, d). Similar results were obtained when HK-2 cells were used in this assay (data not shown). These data demonstrate that HEK293-produced rhGrem1 can inhibit BMP action in a rank order of efficacy similar to that seen with commercially available rhGrem1 (R\&D Systems), and support the rank order of BMP-2>4>7 in terms of Grem1 binding.

Cell-associated Gremlin1 does not inhibit BMP-mediated signalling responses

As previously reported, Grem1 is a secreted protein but also exists in cell-associated forms [1, 21]. Grem1 has been shown to bind to heparin and heparin sulphate proteoglycans, thus modulating its interaction with the VEGFR2 and subsequent pro-angiogenic activity [43]. Other evidence demonstrated that Grem1 acts intracellularly to regulate BMP-4 activation and secretion [23]. In order to assess the ability of 'cell associated' versus 'soluble' Grem1 to inhibit BMP action, HK-2 cells were pre-treated with medium supplemented with vehicle or $25 \mu \mathrm{g} / \mathrm{ml}$ rhGrem1 for $60 \mathrm{~min}$ (Fig. 8b, d, Grem1 pre-incubation, removal and BMP-2 addition, right panels). The Grem1 containing medium was removed and cells were then treated with medium containing $4 \mathrm{mM} \mathrm{HCl}$ (BMP vehicle) or 5 ng/ml BMP-2 (Fig. 8b, d, Grem1 pre-incubation, removal and BMP-2 addition, right panels) for a further $60 \mathrm{~min}$. Similar to previous data, treatment of HK-2 cells with $5 \mathrm{ng} / \mathrm{ml}$ BMP-2 triggered a robust increase in Smad1/5/8 phosphorylation that was completely inhibited by co-incubation with 25 ng/ml Grem1 (Fig. 8a, c, BMP-2 plus Grem1, left panels). In contrast, pre-treatment of HK-2 cells with $25 \mathrm{ng} / \mathrm{ml}$ rhGrem 1 followed by removal of the Grem1-containing medium did not inhibit BMP-2 mediated Smad1/5/8 phosphorylation (Fig. 8b, d, Grem1 pre-incubation, removal and BMP-2 addition, right panels). A similar profile of inhibition was obtained when BMP-4 was used (Suppl. Fig. 4 ). These data suggest that 'cell associated' or surface bound rhGrem1 is unable to inhibit BMP- mediated endogenous BMP type I/II receptor activation and Smad1/5/8 phosphorylation, compared to extracellular rhGrem1 in solution. 


\section{Discussion}

In this study, we identify that BMP proteins have differing affinities for the antagonist Grem1. Calculation of $\mathrm{Kd}$ values from SPR experiments at all concentrations of rhGrem1 examined was somewhat confounded by what appeared to be irreversible, or ultra-tight, binding events at low hGrem1 concentrations (10-300 nM). Nonetheless, when we fitted the reversible rhGrem1-binding phases (i.e 1 or $3 \mu \mathrm{M}$ rhGrem1) to either one-site (Fig. 2b) or bivalent analyte binding model (data not shown), very similar rank orders of binding affinity were observed in vitro: BMP-4 $\geq$ BMP-2 > BMP$6>$ BMP-7 (Table 2). Whilst the apparent 'stickiness' of BMPs to SEC columns precluded robust SEC-MALS experiments and labelling of most BMPs for MST experiments, the one interaction that we could directly measure in vitro (BMP-4/rhGrem1) to independently benchmark the SPR data, had an apparent Kd value that agreed well with the value using the Langmuir analysis (Fig. 2e). Thus, we believe that the observed SPR data is a synthesis of irreversible binding (perhaps caused by the stickiness of BMPs) and reversible binding.

The nature and complexity of these interactions, combined with high cost of the recombinant proteins used here, and their challenging properties, conspired to make in vitro biophysical experiments very challenging. Further work will be needed to disentangle fully the precise mechanism interaction stoichiometry and 'true affinities'. Nonetheless, we feel that the good agreement between the rank order of BMP-rhGrem1 interaction affinities reported here, and their associated biological activities and potencies in cellular experiments, represent an important step forward in higher resolution mechanistic and functional studies. . Protein related to Dan and Cerberus (PRDC or Grem2) also inhibits BMP-2 action in cell culture and whole Xenopus embryos via the formation of highly stable non-covalent dimers [44]. $\mathrm{K}_{\mathrm{D}}$ values estimated by Langmuir equation for Grem1 binding to BMP-2 and BMP-4 were in the same range (low $\mathrm{nM}$ ) as those calculated for PRDC, with the same caveats in place regarding Grem1-BMP affinities we present here. Other authors have shown that reduction of PRDC (Grem2) using DTT changed its mobility on SDS-PAGE, but not its BMP inhibitory activity [44].

Using HK-2 kidney epithelial cells, the ability of Grem1 to inhibit BMP-activated Smad1/5/8 phosphorylation and downstream target gene transcription was defined (Fig. 4, 5). In contrast to the SPR assays where only recombinant Grem1 and BMPs were present, this system measures Grem1BMP competitive binding in the presence of the type I/II BMP receptors in a cell-based assay. The ability of BMP-7 to trigger Smad signalling in these cells was much lower than that of BMP-2 (Fig. $3 \mathrm{a}, \mathrm{b}$ versus c). Complete inhibition of BMP-2 activity was seen with a 3.35 molar excess of Grem1, whereas a 13.6-fold molar excess of Grem1 was required to inhibit BMP-4 (Fig. 4, 5). In contrast, no significant inhibition of BMP-7 was seen with a 16.3-fold molar excess of Grem1 (Fig. 4, 5). Given that BMP-7 can strongly activate pSmad1/5/8 in outgrowth endothelial cells in our laboratory, we do not think that the fidelity of the recombinant BMP-7 is an issue here. Importantly, ACVR1/ALK2 and BMPRIA/ALK3 receptor mRNA was detected in HK-2 cells, suggesting that the reduced response to BMP-7 was not due to an absence of cognate receptors.

Transfection of HEK293 cells with myc-hGrem1 decreased BMP-2 mediated pSmad1/5 phosphorylation (Fig. 6a). Similar profiles of inhibition were observed when conditioned medium from these HEK293 cells transfected was used as a source of Grem1 (Fig. 7). These data suggest that the relative affinity profile seen in our experiments is not dependent on the source of Grem1 used. In addition, the consistent results with two independent sources of rhGrem1 suggest that that myc affinity tag present in rhGrem1 produced from HEK293 cells does not greatly alter Grem1 function or availability in the conditioned medium. How does Grem1 inhibit BMP action? Our data suggests that binding of Grem1 to BMPs in solution is required for its inhibitory activity, as cell-bound Grem1 was not sufficient for inhibition of BMP action (Fig. 8). These data also suggest that rhGrem1 is not binding to and preventing access to the BMP receptors. Previous groups have identified that Grem1 can interact with several cell surface receptors including VEGFR2 and heparin sulphate proteoglycans $[43,45]$. Our data suggest that these cell surface receptor interactions do not "capture" sufficient Grem1 to allow significant inhibition of BMP signalling in HK-2 cells. A different model may exist in endothelial and other vascular cell types that express higher levels of VEGFR2. Apart from direct antagonism of BMP-receptor binding, Grem1 can bind BMP-4 inside C2C12 cells and inhibit BMP-4 maturation and secretion [23]. Recent data has also demonstrated that Grem1 can accelerate the endocytosis of BMP-2 into HeLa cells [22]. Given the relatively short duration of Grem1-BMP treatment of HK-2 cells in our experiments $(60 \mathrm{~min})$, we suggest that the main mechanism of Grem1- 
mediated inhibition of BMP signalling in our experiments is via direct antagonism of BMP in solution, preventing binding to its target receptors at the plasma membrane.

What implications do these data have for those working on the regulation of BMP signalling by Grem1 and other antagonists? We and others have shown that Grem1 levels increase during DN whereas levels of BMP-7 decrease [33,46]. Strategies that stimulate BMP-7 signalling have been shown to attenuate renal fibrosis [5, 12-17], and reductions in Grem1 levels have a similar beneficial effect in mouse models of DN $[32,37]$. In vivo reduction of Grem1 via siRNA targeting recovered BMP-7 levels, suggesting that elevated Grem1 may have a role in repressing BMP-7 in DN [37]. However, our data suggests that this is unlikely to occur via a direct interaction between Grem1 and BMP-7, given their low binding affinity. Small molecules such as tilerone (which induces BMP-7) and Thr123 (which activates the Alk3 BMP receptor) have been shown to reduce kidney fibrosis in vivo $[47,48]$. Together with a recent report showing that an anti-Grem 1 antibody can reduce fibrosis in a model of pulmonary artery hypertension (PAH) [49], these data illustrate that manipulation of the Grem1-BMP signalling axis may still be a useful therapeutic avenue for the treatment of diabetic kidney disease. A recent paper identified that twisted gastrulation (Twsg1) is the most abundant BMP antagonist expressed in cultured kidney podocytes, and could inhibit both BMP-4 and BMP-7 in these cells [20]. This report highlights the likely involvement of multiple BMP antagonists in the control of BMP action during kidney injury.

In summary, we have demonstrated a differential level of activity of BMPs in HK-2 epithelial cells, and a BMP-2>4>7 rank order of Grem1 antagonist binding to these proteins. Our data provide a mechanistic insight into the possible molecular interactions in the diseased kidney in diabetes and other chronic nephropathies.

\section{Disclosure Statement}

None of the authors has a financial interest in the information contained in the manuscript.

\section{Acknowledgements}

The authors thank Dr. John Crean and Dr. Gerard Cagney (UCD Conway Institute, University College Dublin) and Dr. Christopher M. Johnson (MRC Laboratory for Molecular Biology, Cambridge) for helpful discussions. RC is supported by a Biotechnology and Biological Sciences Research Council (BBSRC) CASE PhD studentship, in partnership with AstraZeneca UK. Work in the laboratory of DPB is supported by DEL Northern Ireland, BBSRC, Northern Ireland Kidney Research Fund and Diabetes UK. 


\section{References}

1 Walsh, D. W., Godson, C., Brazil, D. P. and Martin, F. (2010) Extracellular BMP-antagonist regulation in development and disease: tied up in knots. Trends in cell biology. 20, 244-256

2 Rider, C. C. and Mulloy, B. (2010) Bone morphogenetic protein and growth differentiation factor cytokine families and their protein antagonists. The Biochemical journal. 429, 1-12

3 Rosen, V. (2006) BMP and BMP inhibitors in bone. Annals of the New York Academy of Sciences. 1068, 19-25

$4 \quad$ Simic, P. and Vukicevic, S. (2005) Bone morphogenetic proteins in development and homeostasis of kidney. Cytokine \& growth factor reviews. 16, 299-308

5 Zeisberg, M. (2006) Bone morphogenic protein-7 and the kidney: current concepts and open questions. Nephrology, dialysis, transplantation : official publication of the European Dialysis and Transplant Association - European Renal Association. 21, 568-573

6 Jena, N., Martin-Seisdedos, C., McCue, P. and Croce, C. M. (1997) BMP7 null mutation in mice: developmental defects in skeleton, kidney, and eye. Experimental cell research. 230, 28-37

7 Zhao, G. Q. (2003) Consequences of knocking out BMP signaling in the mouse. Genesis. 35, 43-56

8 Tominaga, T., Abe, H., Ueda, O., Goto, C., Nakahara, K., Murakami, T., Matsubara, T., Mima, A., Nagai, K., Araoka, T., Kishi, S., Fukushima, N., Jishage, K. and Doi, T. (2011) Activation of bone morphogenetic protein 4 signaling leads to glomerulosclerosis that mimics diabetic nephropathy. The Journal of biological chemistry. 286, 20109-20116

9 Grgurevic, L., Macek, B., Healy, D. R., Brault, A. L., Erjavec, I., Cipcic, A., Grgurevic, I., Rogic, D., Galesic, K., Brkljacic, J., Stern-Padovan, R., Paralkar, V. M. and Vukicevic, S. (2011) Circulating bone morphogenetic protein 1-3 isoform increases renal fibrosis. Journal of the American Society of Nephrology : JASN. 22, 681-692

10 Yang, Y. L., Ju, H. Z., Liu, S. F., Lee, T. C., Shih, Y. W., Chuang, L. Y., Guh, J. Y., Yang, Y. Y., Liao, T. N., Hung, T. J. and Hung, M. Y. (2011) BMP-2 suppresses renal interstitial fibrosis by regulating epithelial-mesenchymal transition. Journal of cellular biochemistry. 112, 2558-2565

11 Yang, Y. L., Liu, Y. S., Chuang, L. Y., Guh, J. Y., Lee, T. C., Liao, T. N., Hung, M. Y. and Chiang, T. A. (2009) Bone morphogenetic protein-2 antagonizes renal interstitial fibrosis by promoting catabolism of type I transforming growth factor-beta receptors. Endocrinology. 150, 727 740

12 Boon, M. R., van der Horst, G., van der Pluijm, G., Tamsma, J. T., Smit, J. W. and Rensen, P. C. (2011) Bone morphogenetic protein 7: a broad-spectrum growth factor with multiple target therapeutic potency. Cytokine \& growth factor reviews. 22, 221-229

13 Zeisberg, M., Hanai, J., Sugimoto, H., Mammoto, T., Charytan, D., Strutz, F. and Kalluri, R. (2003) BMP-7 counteracts TGF-beta1-induced epithelial-to-mesenchymal transition and reverses chronic renal injury. Nature medicine. 9, 964-968

14 Morrissey, J., Hruska, K., Guo, G., Wang, S., Chen, Q. and Klahr, S. (2002) Bone morphogenetic protein-7 improves renal fibrosis and accelerates the return of renal function. Journal of the American Society of Nephrology : JASN. 13 Suppl 1, S14-21

15 Manson, S. R., Niederhoff, R. A., Hruska, K. A. and Austin, P. F. (2011) Endogenous BMP-7 is a critical molecular determinant of the reversibility of obstruction-induced renal injuries. American journal of physiology. Renal physiology. 301, F1293-1302

16 Manson, S. R., Niederhoff, R. A., Hruska, K. A. and Austin, P. F. (2011) The BMP-7Smad1/5/8 pathway promotes kidney repair after obstruction induced renal injury. The Journal of urology. 185, 2523-2530

17 Nguyen, T. Q. and Goldschmeding, R. (2008) Bone morphogenetic protein-7 and connective tissue growth factor: novel targets for treatment of renal fibrosis? Pharmaceutical research. 25, 24162426

18 Murray, L. A., Hackett, T. L., Warner, S. M., Shaheen, F., Argentieri, R. L., Dudas, P., Farrell, F. X. and Knight, D. A. (2008) BMP-7 does not protect against bleomycin-induced lung or skin fibrosis. PloS one. 3, e4039 
19 Dudas, P. L., Argentieri, R. L. and Farrell, F. X. (2009) BMP-7 fails to attenuate TGF-beta1induced epithelial-to-mesenchymal transition in human proximal tubule epithelial cells. Nephrology, dialysis, transplantation : official publication of the European Dialysis and Transplant Association European Renal Association. 24, 1406-1416

20 Yamada, S., Nakamura, J., Asada, M., Takase, M., Matsusaka, T., Iguchi, T., Yamada, R., Tanaka, M., Higashi, A. Y., Okuda, T., Asada, N., Fukatsu, A., Kawachi, H., Graf, D., Muso, E., Kita, T., Kimura, T., Pastan, I., Economides, A. N. and Yanagita, M. (2014) Twisted Gastrulation, a BMP Antagonist, Exacerbates Podocyte Injury. PloS one. 9, e89135

21 Wordinger, R. J., Zode, G. and Clark, A. F. (2008) Focus on molecules: gremlin. Experimental eye research. 87, 78-79

22 Alborzinia, H., Schmidt-Glenewinkel, H., Ilkavets, I., Breitkopf-Heinlein, K., Cheng, X., Hortschansky, P., Dooley, S. and Wolfl, S. (2013) Quantitative kinetics analysis of BMP2 uptake into cells and its modulation by BMP antagonists. Journal of cell science. 126, 117-127

23 Sun, J., Zhuang, F. F., Mullersman, J. E., Chen, H., Robertson, E. J., Warburton, D., Liu, Y. H. and Shi, W. (2006) BMP4 activation and secretion are negatively regulated by an intracellular gremlin-BMP4 interaction. The Journal of biological chemistry. 281, 29349-29356

24 Khokha, M. K., Hsu, D., Brunet, L. J., Dionne, M. S. and Harland, R. M. (2003) Gremlin is the BMP antagonist required for maintenance of Shh and Fgf signals during limb patterning. Nature genetics. 34, 303-307

25 Michos, O., Panman, L., Vintersten, K., Beier, K., Zeller, R. and Zuniga, A. (2004) Gremlinmediated BMP antagonism induces the epithelial-mesenchymal feedback signaling controlling metanephric kidney and limb organogenesis. Development. 131, 3401-3410

26 Canalis, E., Parker, K. and Zanotti, S. (2012) Gremlin1 is required for skeletal development and postnatal skeletal homeostasis. Journal of cellular physiology. 227, 269-277

27 Michos, O., Goncalves, A., Lopez-Rios, J., Tiecke, E., Naillat, F., Beier, K., Galli, A., Vainio, S. and Zeller, R. (2007) Reduction of BMP4 activity by gremlin 1 enables ureteric bud outgrowth and GDNF/WNT11 feedback signalling during kidney branching morphogenesis. Development. 134, 2397-2405

28 Goncalves, A. and Zeller, R. (2011) Genetic analysis reveals an unexpected role of BMP7 in initiation of ureteric bud outgrowth in mouse embryos. PloS one. 6, e19370

29 Lappin, D. W., McMahon, R., Murphy, M. and Brady, H. R. (2002) Gremlin: an example of the re-emergence of developmental programmes in diabetic nephropathy. Nephrology, dialysis, transplantation : official publication of the European Dialysis and Transplant Association - European Renal Association. 17 Suppl 9, 65-67

30 Li, G., Li, Y., Liu, S., Shi, Y., Chi, Y., Liu, G. and Shan, T. (2013) Gremlin aggravates hyperglycemia-induced podocyte injury by a TGFbeta/smad dependent signaling pathway. Journal of cellular biochemistry. 114, 2101-2113

31 McMahon, R., Murphy, M., Clarkson, M., Taal, M., Mackenzie, H. S., Godson, C., Martin, F. and Brady, H. R. (2000) IHG-2, a mesangial cell gene induced by high glucose, is human gremlin. Regulation by extracellular glucose concentration, cyclic mechanical strain, and transforming growth factor-beta1. The Journal of biological chemistry. 275, 9901-9904

32 Roxburgh, S. A., Kattla, J. J., Curran, S. P., O'Meara, Y. M., Pollock, C. A., Goldschmeding, R., Godson, C., Martin, F. and Brazil, D. P. (2009) Allelic depletion of grem1 attenuates diabetic kidney disease. Diabetes. 58, 1641-1650

33 Walsh, D. W., Roxburgh, S. A., McGettigan, P., Berthier, C. C., Higgins, D. G., Kretzler, M., Cohen, C. D., Mezzano, S., Brazil, D. P. and Martin, F. (2008) Co-regulation of Gremlin and Notch signalling in diabetic nephropathy. Biochimica et biophysica acta. 1782, 10-21

34 Carvajal, G., Droguett, A., Burgos, M. E., Aros, C., Ardiles, L., Flores, C., Carpio, D., RuizOrtega, M., Egido, J. and Mezzano, S. (2008) Gremlin: a novel mediator of epithelial mesenchymal transition and fibrosis in chronic allograft nephropathy. Transplantation proceedings. 40, 734-739 35 Mezzano, S., Droguett, A., Burgos, M. E., Aros, C., Ardiles, L., Flores, C., Carpio, D., Carvajal, G., Ruiz-Ortega, M. and Egido, J. (2007) Expression of gremlin, a bone morphogenetic protein antagonist, in glomerular crescents of pauci-immune glomerulonephritis. Nephrology, dialysis, transplantation : official publication of the European Dialysis and Transplant Association European Renal Association. 22, 1882-1890 
36 Koli, K., Myllarniemi, M., Vuorinen, K., Salmenkivi, K., Ryynanen, M. J., Kinnula, V. L. and Keski-Oja, J. (2006) Bone morphogenetic protein-4 inhibitor gremlin is overexpressed in idiopathic pulmonary fibrosis. The American journal of pathology. 169, 61-71

37 Zhang, Q., Shi, Y., Wada, J., Malakauskas, S. M., Liu, M., Ren, Y., Du, C., Duan, H., Li, Y., Li, Y. and Zhang, Y. (2010) In vivo delivery of Gremlin siRNA plasmid reveals therapeutic potential against diabetic nephropathy by recovering bone morphogenetic protein-7. PloS one. 5, e11709 38 Carew, R. M., Browne, M. B., Hickey, F. B. and Brazil, D. P. (2011) Insulin receptor substrate 2 and FoxO3a signalling are involved in E-cadherin expression and transforming growth factor-beta 1-induced repression in kidney epithelial cells. Febs J. 278, 3370-3380

39 Curran, S. P., Hickey, F. B., Watson, A., Godson, C. and Brazil, D. P. (2012) Deletion of Gremlin1 increases cell proliferation and migration responses in mouse embryonic fibroblasts. Cellular signalling. 24, 889-898

40 Mazerbourg, S. and Hsueh, A. J. (2006) Genomic analyses facilitate identification of receptors and signalling pathways for growth differentiation factor 9 and related orphan bone morphogenetic protein/growth differentiation factor ligands. Human reproduction update. 12, 373-383 41 Leeuwis, J. W., Nguyen, T. Q., Chuva de Sousa Lopes, S. M., van der Giezen, D. M., van der Ven, K., Rouw, P. J., Offerhaus, G. J., Mummery, C. L. and Goldschmeding, R. (2011) Direct visualization of Smad1/5/8-mediated transcriptional activity identifies podocytes and collecting ducts as major targets of BMP signalling in healthy and diseased kidneys. The Journal of pathology. 224, 121-132

42 Macias-Silva, M., Hoodless, P. A., Tang, S. J., Buchwald, M. and Wrana, J. L. (1998) Specific activation of Smad1 signaling pathways by the BMP7 type I receptor, ALK2. The Journal of biological chemistry. 273, 25628-25636

43 Chiodelli, P., Mitola, S., Ravelli, C., Oreste, P., Rusnati, M. and Presta, M. (2011) Heparan sulfate proteoglycans mediate the angiogenic activity of the vascular endothelial growth factor receptor-2 agonist gremlin. Arteriosclerosis, thrombosis, and vascular biology. 31, e116-127

44 Kattamuri, C., Luedeke, D. M., Nolan, K., Rankin, S. A., Greis, K. D., Zorn, A. M. and Thompson, T. B. (2012) Members of the DAN Family Are BMP Antagonists That Form Highly Stable Noncovalent Dimers. J Mol Biol. 424, 313-327

45 Mitola, S., Ravelli, C., Moroni, E., Salvi, V., Leali, D., Ballmer-Hofer, K., Zammataro, L. and Presta, M. (2010) Gremlin is a novel agonist of the major proangiogenic receptor VEGFR2. Blood. 116, 3677-3680

46 Wang, S. N., Lapage, J. and Hirschberg, R. (2001) Loss of tubular bone morphogenetic protein-7 in diabetic nephropathy. Journal of the American Society of Nephrology : JASN. 12, 23922399

47 Lepparanta, O., Tikkanen, J. M., Bespalov, M. M., Koli, K. and Myllarniemi, M. (2013) Bone morphogenetic protein-inducer tilorone identified by high-throughput screening is antifibrotic in vivo. American journal of respiratory cell and molecular biology. 48, 448-455

48 Sugimoto, H., LeBleu, V. S., Bosukonda, D., Keck, P., Taduri, G., Bechtel, W., Okada, H., Carlson, W., Jr., Bey, P., Rusckowski, M., Tampe, B., Tampe, D., Kanasaki, K., Zeisberg, M. and Kalluri, R. (2012) Activin-like kinase 3 is important for kidney regeneration and reversal of fibrosis. Nature medicine. 18, 396-404

49 Ciuclan, L., Sheppard, K., Dong, L., Sutton, D., Duggan, N., Hussey, M., Simmons, J., Morrell, N. W., Jarai, G., Edwards, M., Dubois, G., Thomas, M., Van Heeke, G. and England, K. (2013) Treatment with Anti-Gremlin 1 Antibody Ameliorates Chronic Hypoxia/SU5416-Induced Pulmonary Arterial Hypertension in Mice. The American journal of pathology. 183, 1461-1473 


\begin{tabular}{|c|c|c|c|}
\hline & $\begin{array}{c}\text { Predicted size (kDa) } \\
\text { (R\&D Systems) }\end{array}$ & $\begin{array}{c}\text { SDS-PAGE (kDa) } \\
\text { (reducing) }\end{array}$ & $\begin{array}{c}\text { Observed SDS-PAGE (kDa) } \\
\text { (non-reducing) }\end{array}$ \\
\hline Grem1 & 19.7 & $25-30$ & $\sim 25$ \\
\hline BMP-2 & 13 & $15-16$ & 30 \\
\hline BMP-4 & 13 & $22-25$ & 35 \\
\hline BMP-6 & 15 & 18 & 30 \\
\hline BMP-7 & 15.7 & $18-20$ & 28 \\
\hline
\end{tabular}

Table 1. Predicted vs. observed molecular weights of rhGrem1, BMP-2, BMP-4, BMP-6 and BMP-7. Predicted molecular weights of the recombinant proteins were obtained from product datasheets from R\&D systems. Observed molecular weights were obtained from Coomassie staining or Western blotting of recombinant proteins separated by SDS-PAGE under reducing or non-reducing conditions. 
1:1 Langmuir analysis

\begin{tabular}{|c|c|c|c|}
\hline Protein & $\begin{array}{c}\boldsymbol{K}_{\text {ON }} \\
\left(\mathbf{M}^{-1} \mathbf{s}^{-1} \mathbf{)}\right.\end{array}$ & $\begin{array}{c}\text { KoFF } \\
\left(\mathbf{s}^{-1}\right)\end{array}$ & $\begin{array}{c}\boldsymbol{K}_{\mathbf{d}} \\
\mathbf{( M )}\end{array}$ \\
\hline BMP-2 & $1.0 \times 10^{4}$ & $3.3 \times 10^{-4}$ & $32 \times 10^{-9}$ \\
\hline BMP-4 & $1.2 \times 10^{4}$ & $3.3 \times 10^{-4}$ & $28 \times 10^{-9}$ \\
\hline BMP-6 & $6.8 \times 10^{3}$ & $5.1 \times 10^{-4}$ & $76 \times 10^{-9}$ \\
\hline BMP-7 & $1.0 \times 10^{4}$ & $9.2 \times 10^{-4}$ & $88 \times 10^{-9}$ \\
\hline
\end{tabular}

Table 2. Binding affinities of Grem1 for recombinant BMPs. Sensorgrams obtained for Grem1 binding to each rhBMP were analysed using a 1:1 Langmuir binding model analysis with BiaEvaluation software allowing $\mathrm{K}_{\mathrm{ON}}, \mathrm{K}_{\mathrm{OFF}}$ and dissociation $\left(\mathrm{K}_{\mathrm{D}}\right)$ rate constants to be calculated. Data shown are a mean of duplicate values. 


\begin{tabular}{|c|c|c|c|c|c|c|}
\hline Protein & $\begin{array}{c}\mathbf{k o N}^{\mathbf{1}} \\
\left(\mathbf{M}^{-1} \mathbf{s}^{-1}\right)\end{array}$ & $\begin{array}{c}\mathbf{k o F F}^{\mathbf{1}} \\
\left(\mathbf{s}^{-1}\right)\end{array}$ & $\begin{array}{c}\boldsymbol{K}_{\mathbf{d}} \mathbf{1} \\
(\mathbf{M})\end{array}$ & $\begin{array}{c}\mathbf{k o N}^{2} \\
\left(\mathbf{M}^{-1} \mathbf{s}^{-1}\right)\end{array}$ & $\begin{array}{c}\mathbf{k o F}^{\mathbf{2}} \\
\left(\mathbf{s}^{-1}\right)\end{array}$ & $\begin{array}{c}\boldsymbol{K}_{\mathbf{d}} \mathbf{d}^{\mathbf{2}} \\
(\mathbf{M})\end{array}$ \\
\hline BMP-2 & 12,050 & $8.9 \times 10^{-5}$ & $7.4 \times 10^{-9}$ & $4.0 \times 10^{-4}$ & $2.7 \times 10^{-2}$ & 67 \\
\hline BMP-4 & 14,800 & $6.2 \times 10^{-6}$ & $4.2 \times 10^{-10}$ & $8.9 \times 10^{-4}$ & 0.32 & 36 \\
\hline BMP-6 & 20,700 & $2.9 \times 10^{-4}$ & $1.4 \times 10^{-8}$ & $6.3 \times 10^{-3}$ & 0.02 & 4 \\
\hline BMP-7 & 18,600 & $4.6 \times 10^{-4}$ & $2.5 \times 10^{-8}$ & $8.8 \times 10^{-4}$ & $2.6 \times 10^{-2}$ & 29 \\
\hline
\end{tabular}

Supplemental Table 1. Binding affinities of Grem1 for recombinant BMPs. Sensorgrams obtained for Grem1 binding to each rhBMP were analysed using a bivalent model analysis with BiaEvaluation software allowing $\mathrm{K}_{\mathrm{ON}}, \mathrm{K}_{\mathrm{OFF}}$ and dissociation $\left(\mathrm{K}_{\mathrm{D}}\right)$ rate constants for a theoretical two site model to be calculated. Data shown are a mean of duplicate values. 


\section{Figure Legends}

Figure 1. Detection of rhGrem1 and rhBMPs by Coomassie violet staining and Western blot. (a) Recombinant human (rh) Grem1, BMP-2, BMP-4, BMP-6 and BMP-7 samples were prepared at 0.5 $\mu \mathrm{g}$ and $1.0 \mu \mathrm{g}$ via dilution with the appropriate vehicle (PBS (Grem1) or $4 \mathrm{mM} \mathrm{HCl} \mathrm{(BMPs))} \mathrm{and}$ added to an equal volume of $2 \times$ Laemmli buffer in the absence of 2-mercaptoethanol (1:100) and the absence of sample denaturation by boiling. Samples were separated on $10 \%(\mathrm{v} / \mathrm{v})$ SDS-PAGE and stained with Coomassie Violet to visualise the recombinant protein. (b-f) Recombinant human (rh) Grem1, BMP-2, BMP-4, BMP-6 and BMP-7 samples were prepared at $100 \mathrm{ng}$ and $500 \mathrm{ng}$ via dilution with the appropriate vehicle (PBS (Grem1) or $4 \mathrm{mM} \mathrm{HCl}$ (BMPs)) and added to an equal volume of 2 $\mathrm{x}$ Laemmli buffer in the absence of 2-mercaptoethanol (1:100) and the absence of sample denaturation by boiling. Samples were separated by $10 \%(\mathrm{v} / \mathrm{v})$ SDS-PAGE and probed via Western blotting using antibodies reactive to Grem1, BMP-2, BMP-4, BMP-6 or BMP-7 as indicated.

Figure 2. Recombinant hGrem1 binds to recombinant hBMPs with different affinities. (a) Recombinant human BMP-7 was coupled to Xantec HLC 30m SPR sensorchips as described. Increasing concentrations of rhGrem $1(10 \mathrm{nM}-3 \mu \mathrm{M})$ were injected over the surface and the relative binding in response units (RU) was measured. Sensorgrams were subjected to double referencing with subtraction of their respective control sensorgrams and blank injections.. The injection start and end points are indicated. Data shown are respesentative of an individual experiment performed in duplicate. (b) Data were subjected to a 1:1 Langmuir binding analysis using the $3 \mu \mathrm{M}$ Grem1 injection data over immobilised BMPs. The turquoise line indicates the SPR binding curve and the black line indicates the fitting of the 1:1 binding model.(c, d) Size exclusion chromatography (SEC) analysis of rhGrem1 and rhBMP-2. A $5 \mu \mathrm{L}$ aliquot of a $\sim 50 \mu \mathrm{M}$ rhGrem1 (c) or rhBMP-2 (d) was injected onto a $15 \mathrm{~mL}$ analytical KW-803 SEC column. The differential refractive index (dRI) is plotted against elution volume $\left(\mathrm{V}_{\mathrm{e}}\right.$, in $\left.\mathrm{ml}\right)$. For rhGrem1, two species were resolved with the most abundant species eluting at $\sim 12.3 \mathrm{ml}$ (90\% of total sample) and the remaining $10 \%$ eluting earlier $\left(\mathrm{V}_{\mathrm{e}}\right.$ of $\sim 11.9 \mathrm{ml}$. A single elution peak was observed for BMP-2, with a $\mathrm{V}_{\mathrm{e}}$ of $\sim 12.1 \mathrm{ml}$. (e) Titration of rhGrem1 into BMP-4 measured using microscale thermophoresis (MST). Unlabelled rhGrem1 was titrated against fluorescently-labelled BMP-4 (see Methods). A 1:2 dilution series was generated, with $1 \mu \mathrm{M}$ Grem1 as the maximal concentration measured. The fitted MST data yielded apparent $K_{\mathrm{d}}$ values in the range $40-50 \mathrm{nM}$.

Figure 3. Human BMPs exhibit different efficacies of Smad 1/5/8 phosphorylation in HK-2 cells. Human proximal tubule epithelial cells $(\mathrm{HK}-2)$ cells were treated with vehicle $(4 \mathrm{mM} \mathrm{HCl})$ or increasing concentrations of (a) rhBMP-2, (b) rhBMP-4 or (c) rhBMP-7 as indicated for 60 min. Twenty $\mu \mathrm{g}$ of protein lysates were separated by $10 \%$ SDS-PAGE and probed via Western blotting using antibodies reactive to pSmad1/5/8 (top panel) and $\beta$-actin (lower panel). Data are plotted as mean $+/-$ SEM. The results are representative of three independent experiments performed in duplicate. + , positive control lysate. (d) cDNA from human proximal tubule epithelial cells (HK-2) and human embryonic kidney cells (HEK293) was analysed via quantitative PCR using specific Taqman probes for ACVR1 (ALK 2), BMPR1A (ALK 3) and BMPR1B (ALK 6). 18S and $\beta$-actin were used as housekeeping controls. Values shown are relative gene expression $\left(2^{-\Delta \Delta C t}\right.$ (gene minus housekeeping gene average)) +/- SEM. The results are representative of three independent experiments performed in triplicate. Statistical significance was determined using Student's unpaired t-test (two-tailed). ${ }^{* *}, \mathrm{p}<0.01$

Figure 4. Differential Grem1-mediated inhibition of BMP-stimulated Smad 1/5/8 phosphorylation. $\mathrm{HK}-2$ cells were treated with vehicle $(4 \mathrm{mM} \mathrm{HCl}$ ), (a) $5 \mathrm{ng} / \mathrm{ml} \mathrm{rhBMP}-2$, (b) 5 $\mathrm{ng} / \mathrm{ml} \mathrm{rhBMP-4}$ or (c) $20 \mathrm{ng} / \mathrm{ml} \mathrm{rhBMP}-7$ in the absence or presence of increasing concentrations of rhGrem1 as indicated for $60 \mathrm{~min}$. Grem1 and BMP proteins were co-incubated in HK-2 complete medium at $37{ }^{\circ} \mathrm{C}$ for 15 min prior to adding to cells. In (e), an additional control of BMP-2 $(5 \mathrm{ng} / \mathrm{ml})$ and BMP-2 $(5 \mathrm{ng} / \mathrm{ml})$ plus Gremlin $(100 \mathrm{ng} / \mathrm{ml})$ was included to confirm the integrity of the rhGrem1. Twenty $\mu \mathrm{g}$ of protein lysates were separated by $10 \%$ SDS-PAGE and probed via Western blotting using antibodies reactive to $\mathrm{pSmad} 1 / 5 / 8$ (top panel) and $\beta$-actin (lower panel). (b, d, f) Band 
intensities were calculated using Image $\mathrm{J}$ and plotted as a ratio of $\mathrm{pSmad} 1 / 5 / 8$ intensity normalised to $\beta$-actin. Data are plotted as mean $+/$ - SEM. The results are representative of three independent experiments performed in duplicate. + represents the positive control lysate.

Figure 5. Grem1 inhibits BMP-mediated Id1 and Smad6 gene expression with differing affinities. HK-2 cells were treated with vehicle $(4 \mathrm{mM} \mathrm{HCl}),(\mathrm{a}, \mathrm{d}) 10 \mathrm{ng} / \mathrm{ml} \mathrm{rhBMP}-2$, (b, e) 10 $\mathrm{ng} / \mathrm{ml} \mathrm{rhBMP-4}$ or(c, f) $20 \mathrm{ng} / \mathrm{ml}$ rhBMP-7 in the absence or presence of increasing concentrations of rhGrem 1 as indicated for $2 \mathrm{~h}$. Recombinant proteins were co-incubated in HK-2 complete medium at $37^{\circ} \mathrm{C}$ for $15 \mathrm{~min}$ prior to adding to the cells. RNA was extracted, cDNA generated and quantitative PCR was performed using specific Taqman probes for Id1 and Smad6. Relative quantification was obtained using the $\Delta \Delta \mathrm{Ct}$ method using $18 \mathrm{~S}$ and $\beta$-actin as housekeeping controls. The vehicle was used as the calibrator and set to 1 for each experiment. Values are shown as a mean fold change $+/-$ SEM. Statistical significance was determined using a one-way ANOVA with Bonferroni's Multiple Comparison Test. The results are representative of 3 independent experiments performed in triplicate. $*, \mathrm{p}<0.05, * *, \mathrm{p}<0.01$.

Figure 6. Overexpression of human Grem1 inhibits BMP stimulation of Smad1/5/8 phosphorylation in HEK293 cells. (a) HEK293 cells were grown on glass coverslips and transfected with empty plasmid ( $p c D N A 3.1$ ) or plasmid containing full-length human Grem1 cDNA ( $p c D N A 3.1$ $h$ Greml) as described in Methods. Cells were stained with anti-myc antibody and TRITC-labelled anti-mouse secondary to visualise myc-Grem1. PhosphoSmad1/5/8 antibody (Cell Signaling), followed by FITC-labelled anti-rabbit secondary was used to visualise pSmad1/5/8. DAPI was used to visualise cell nuclei. Scale bars represent $50 \mu \mathrm{m}$. (b) Conditioned medium from pcDNA3.1 transfected or pcDNA3.1-myc-hGrem1 transfected cells was harvested, concentrated by centrifugation and probed via SDS-PAGE and Western blotting using anti-Grem1 antibody (R\&D Systems). +, positive control.

Figure 7. Conditioned medium containing human Grem1 inhibits BMP-mediated Smad1/5/8 phosphorylation. (a) Conditioned medium (CM) from pcDNA3.1 or pcDNA3.1-hGrem1-transfected cells was harvested, concentrated via centrifugation and probed using antibody reactive to Grem1 to confirm expression. Fresh HEK293 cells were then treated for 60 min with rhBMP-2 (upper panels), rhBMP-4 (middle panels) or rhBMP-7 (lower panels) in the presence of CM from pcDNA3.1 transfected cells, or a serial dilution of CM from pcDNA3.1-rhGrem1-transfected cells (100\%, neat medium, $50 \%$, 1:2 dilution, $25 \%$, 1:4 dilution, $12.5 \%$, 1: 8 dilution, $5 \%, 1: 20$ dilution). Cells were lysed with RIPA buffer and protein extracts probed using antibodies reactive to $\mathrm{pSmad} 1 / 5 / 8$ or $\beta$-actin as loading control. Band intensities were calculated using Image $J$ and plotted as a mean ratio of pSmad1/5/8 intensity normalised to $\beta$-actin. Data are plotted as mean +/- SD for (b) BMP-2, (c) BMP4 or (d) BMP-7.

Figure 8. Cell associated Grem1 does not inhibit BMP-2 mediated Smad1/5/8 phosphorylation. . (a) A control of vehicle, BMP-2 $5 \mathrm{ng} / \mathrm{ml}$ and BMP-2 $5 \mathrm{ng} / \mathrm{ml}$ plus Grem1 $25 \mathrm{ng} / \mathrm{ml}$, co-incubated in HK-2 complete medium at $37{ }^{\circ} \mathrm{C}$ for 15 min prior to adding to cells for $60 \mathrm{~min}$ was included as a comparison. (b) HK-2 cells were treated with medium containing vehicle (PBS) or $25 \mathrm{ng} / \mathrm{ml} \mathrm{Grem1} \mathrm{as}$ indicated for $60 \mathrm{~min}$. The medium was removed and replaced with medium supplemented with vehicle $(4 \mathrm{mM} \mathrm{HCl})$ or $5 \mathrm{ng} / \mathrm{ml}$ BMP-2 as indicated for a further 60 min Twenty $\mu \mathrm{g}$ of protein lysates were separated by $10 \%$ SDS-PAGE and probed via Western blotting using antibodies reactive to pSmad1/5/8 (top panel) and $\beta$-actin (lower panel). Densitometry analysis with ImageJ software was performed on scanned X-ray films, band intensities were calculated and plotted as a ratio of pSmad1/5/8 intensity normalised to $\beta$-actin $(\mathrm{c}, \mathrm{d})$. Data are plotted as mean $+/$ - SEM. The results are representative of three independent experiments performed in duplicate. + represents the positive control lysate. 
Supplemental Figure 1. Silver stain SDS-PAGE of rhGrem1 and rhBMPs. Recombinant proteins (approx. $50 \mathrm{mM}$ ) were diluted with $2 \times$ Laemmli buffer containing $100 \mathrm{mM}$ DTT and boiled for 5 min. Samples were then loaded onto a $20 \%$ SDS-PAGE gel which was then stained using standard Silver staining protocols. The migration of each protein was calculated using Pierce PageRuler Plus Prestained Protein Ladder. Upper blue band, $35 \mathrm{kDa}$; pink band, $25 \mathrm{kDa}$; lower blue band, $15 \mathrm{kDa}$.

Supplemental Figure 2. rhGrem1 binds to recombinant BMPs with different affinities. (a-d) Recombinant human BMPs were coupled to Xantec HLC 30m SPR sensorchips as described. Increasing concentrations of rhGrem $1(10 \mathrm{nM}-3 \mu \mathrm{M})$ were injected over the surface and the relative binding in response units (RU) was measured. Sensorgrams were subjected to double referencing with subtraction of their respective control sensorgrams and blank injections. Data shown are respesentative of an individual experiment performed in duplicate. (e) A calibration curve was constructed from rhGrem1:rhBMP-2, 4, 6, and 7 dose response sensorgrams. The response units (RU) for individual BMPs were plotted against Gremlin concentration $(\mathrm{nM})$ to estimate binding affinity.

Supplemental Figure 3. Overexpression of human Grem1 in HEK293 cells. (a) HEK293 cells were grown on glass coverslips and transfected with empty plasmid ( $p c D N A 3.1)$ or plasmid containing full-length human Grem1 cDNA ( $p c D N A 3.1-h \mathrm{Greml})$ as described in Methods. Cells were stained with anti-myc antibody and TRITC-labelled anti-mouse secondary to visualise myc-Grem1. Scale bars represent $25 \mu \mathrm{m}$.

Supplemental Figure 4. Cell associated Grem1 does not inhibit BMP-4 mediated Smad1/5/8 phosphorylation. (a) A control of vehicle, BMP-4 $5 \mathrm{ng} / \mathrm{ml}$ and BMP42 $5 \mathrm{ng} / \mathrm{ml}$ plus Grem1 200 $\mathrm{ng} / \mathrm{ml}$, co-incubated in HK-2 complete medium at $37{ }^{\circ} \mathrm{C}$ for $15 \mathrm{~min}$ prior to adding to cells for $60 \mathrm{~min}$ was included as a comparison. (b) HK-2 cells were treated with medium containing vehicle (PBS) or $200 \mathrm{ng} / \mathrm{ml} \mathrm{Grem1} \mathrm{as} \mathrm{indicated} \mathrm{for} 60 \mathrm{~min}$. The medium was removed and replaced with medium supplemented with vehicle $(4 \mathrm{mM} \mathrm{HCl})$ or $5 \mathrm{ng} / \mathrm{ml} \mathrm{BMP}-4$ as indicated for a further $60 \mathrm{~min}$. Twenty $\mu \mathrm{g}$ of protein lysates were separated by $10 \%$ SDS-PAGE and probed via Western blotting using antibodies reactive to $\mathrm{pSmad1/5/8}$ (top panel) and $\beta$-actin (lower panel). Densitometry analysis with ImageJ software was performed on scanned X-ray films, band intensities were calculated and plotted as a ratio of $\mathrm{pSmad} 1 / 5 / 8$ intensity normalised to $\beta$-actin $(\mathrm{c}, \mathrm{d})$. Data are plotted as mean $+/-\mathrm{SEM}$. The results are representative of three independent experiments performed in duplicate. + represents the positive control lysate. 


\section{Abbreviations}

ALK - Activin receptor-like kinase

BMP - Bone morphogenetic protein

$\mathrm{C} 2 \mathrm{C} 12$ - ouse myoblast cell line

cDNA - complementary DNA

DAPI - 4',6-Diamidino-2-Phenylindole, Dihydrochloride

DN - diabetic nephropathy

EDC - 1-ethyl-3-(3-dimethylaminopropyl)carbodimide

FITC - fluorescein

Grem1 - Gremlin1

$\mathrm{HCl}$ - hydrochloric acid

HEK293 - human embryonic kidney cells

HeLa - humal epithelial adenocarcinoma cells

HEPES - 4-(2-hydroxyethyl)-1-piperazineethanesulfonic acid

HK-2 - human kidney epithelial cells

$\mathrm{KCl}$ - potassium chloride

$\mathrm{NaCl}$ - sodium chloride

NHS - N-hydroxysuccinimide

$\mathrm{M}-$ molar

MST - microscale thermophoresis

MW - molecular weight

PAH - Pulmonary Artery Hypertension

PBS - phosphate buffered saline

PRDC - Protein related to Dan and Cerberus/Gremlin2

rh - recombinant human

$\mathrm{rm}$ - recombinant mouse

RIPA - radioimmunoprecipitation lysis buffer

RT-PCR - real time polymerase chain reaction

SEC-MALS - size exclusion chromatography in conjunction with multi angle light scattering SDS-PAGE - sodium dodecyl sulfate polyacrylamide gel electrophoresis 
SMAD - Sma and Mad (Mothers against decapentaplegic)

SPR - surface plasmon resonance

STZ - streptozotocin

siRNA - small interfering RNA

TGF- $\beta$ - transforming growth factor beta

TRITC - Tetramethylrhodamine

Twsg1 - Twisted gastrulation

VEGFR2 - Vascular endothelial growth factor receptor 2 
Figure 1.

a.

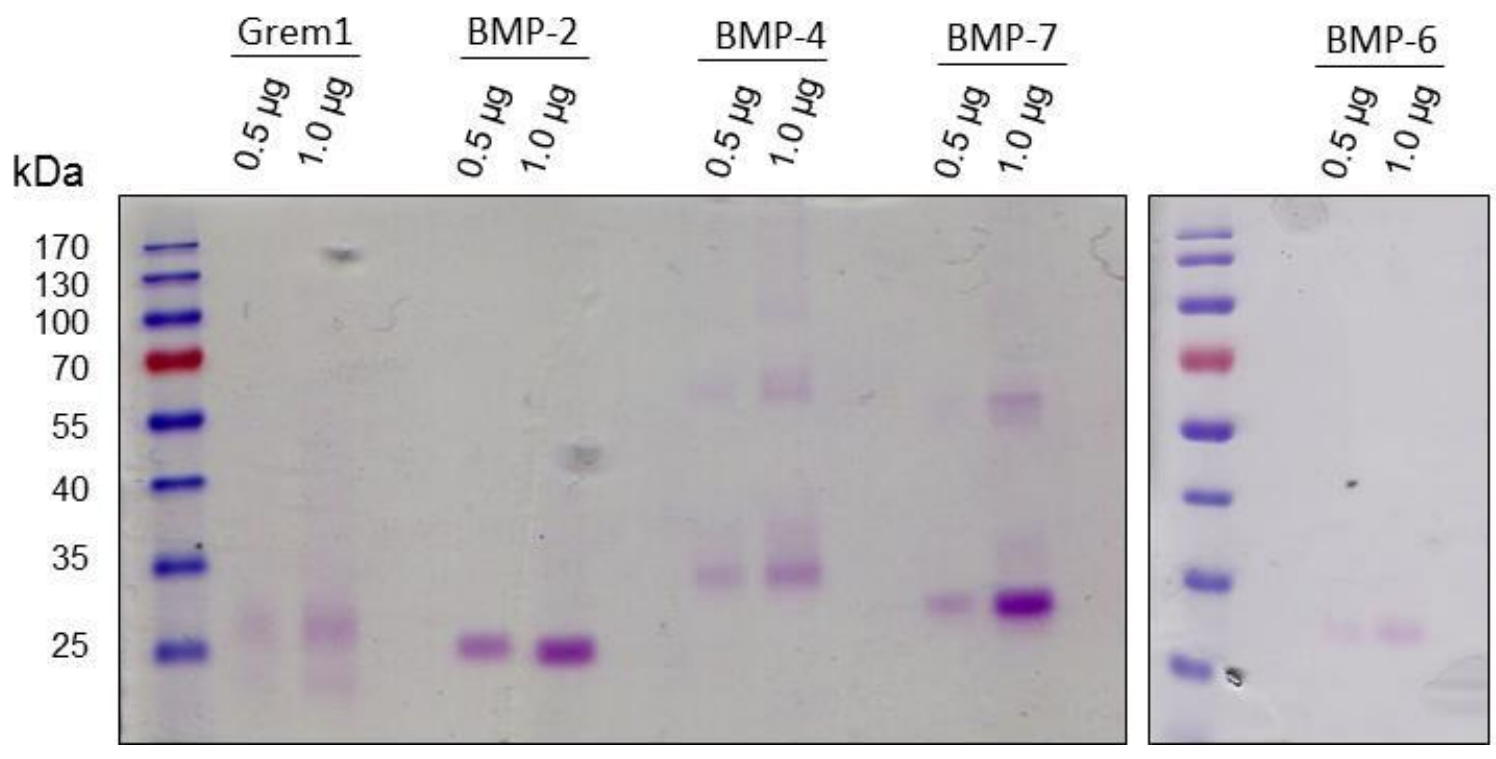

b.

c.

d.

e.

f.
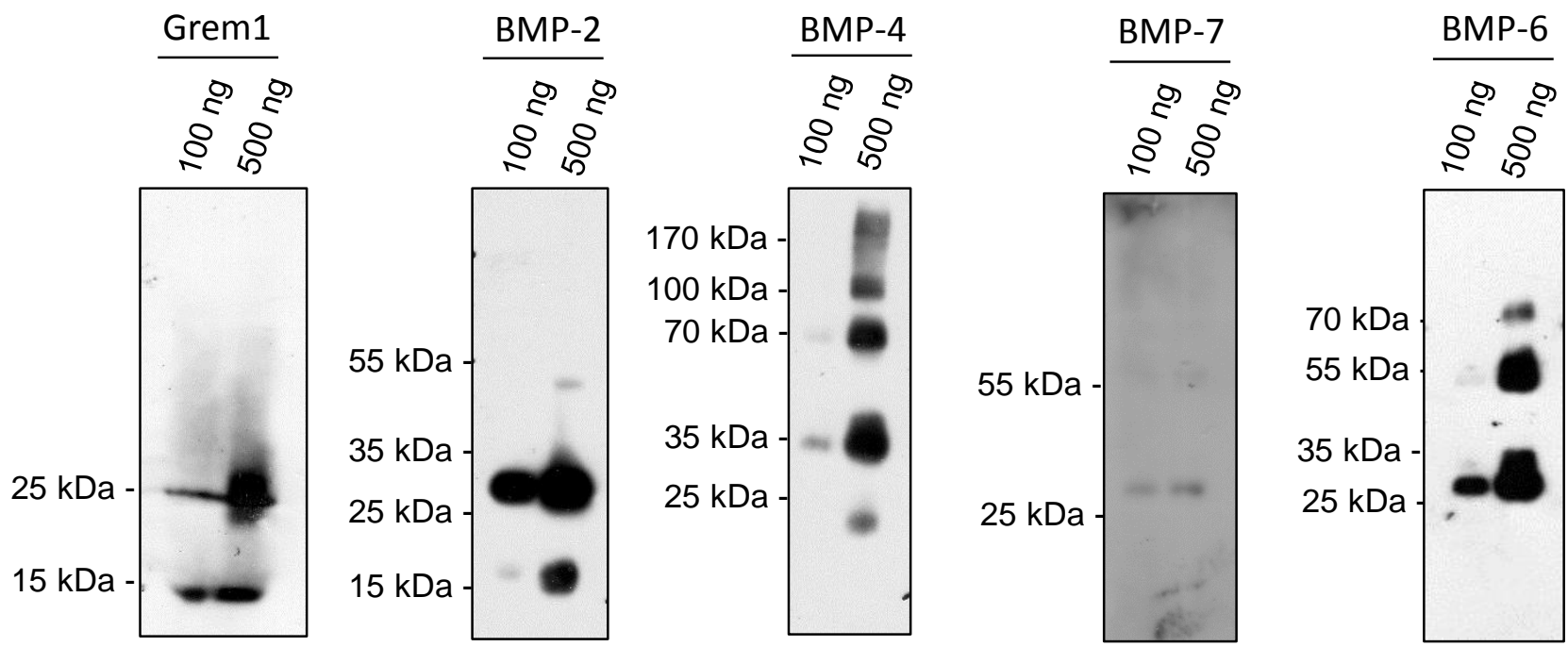
Figure 2.

a.

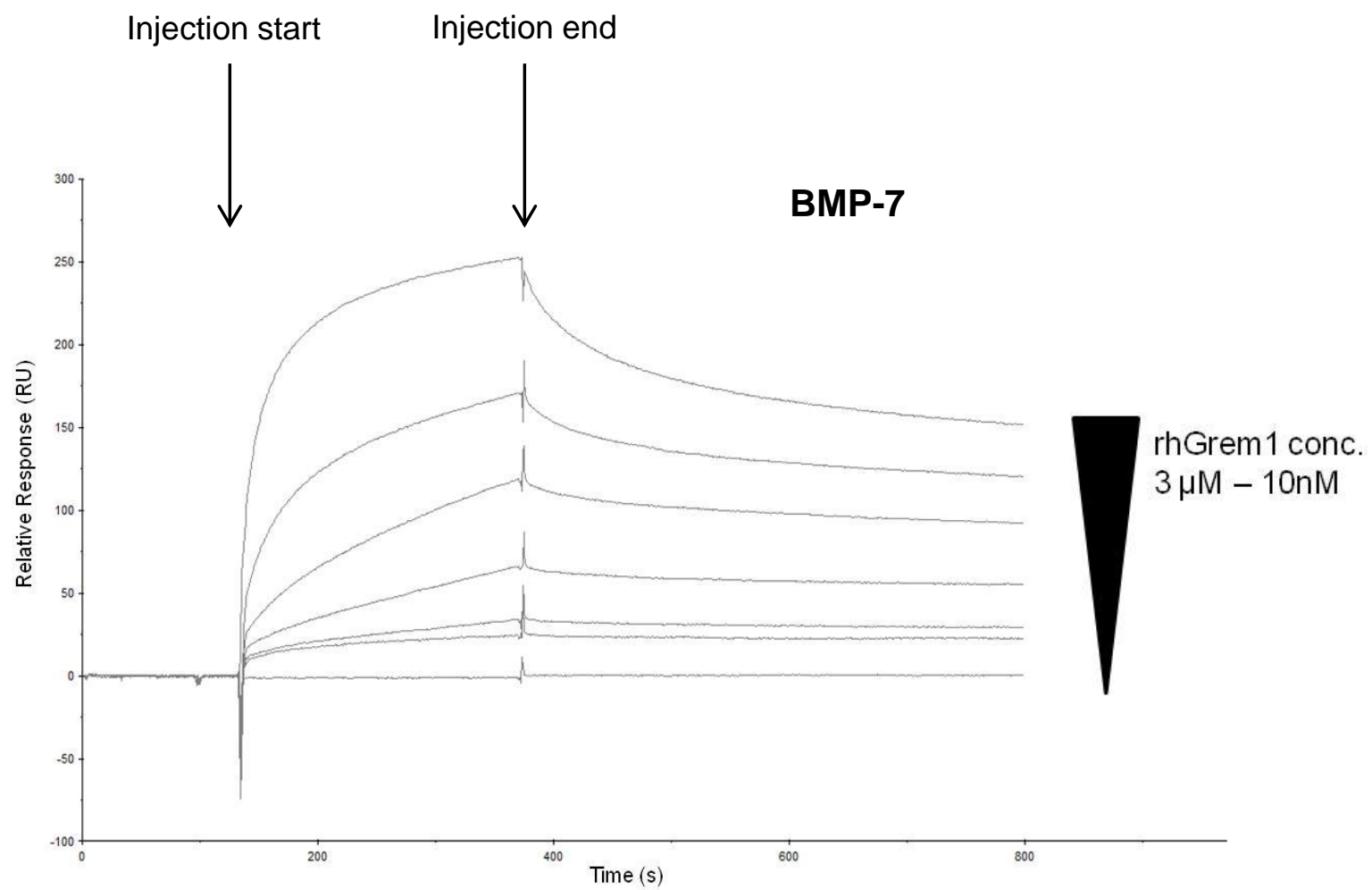

b.

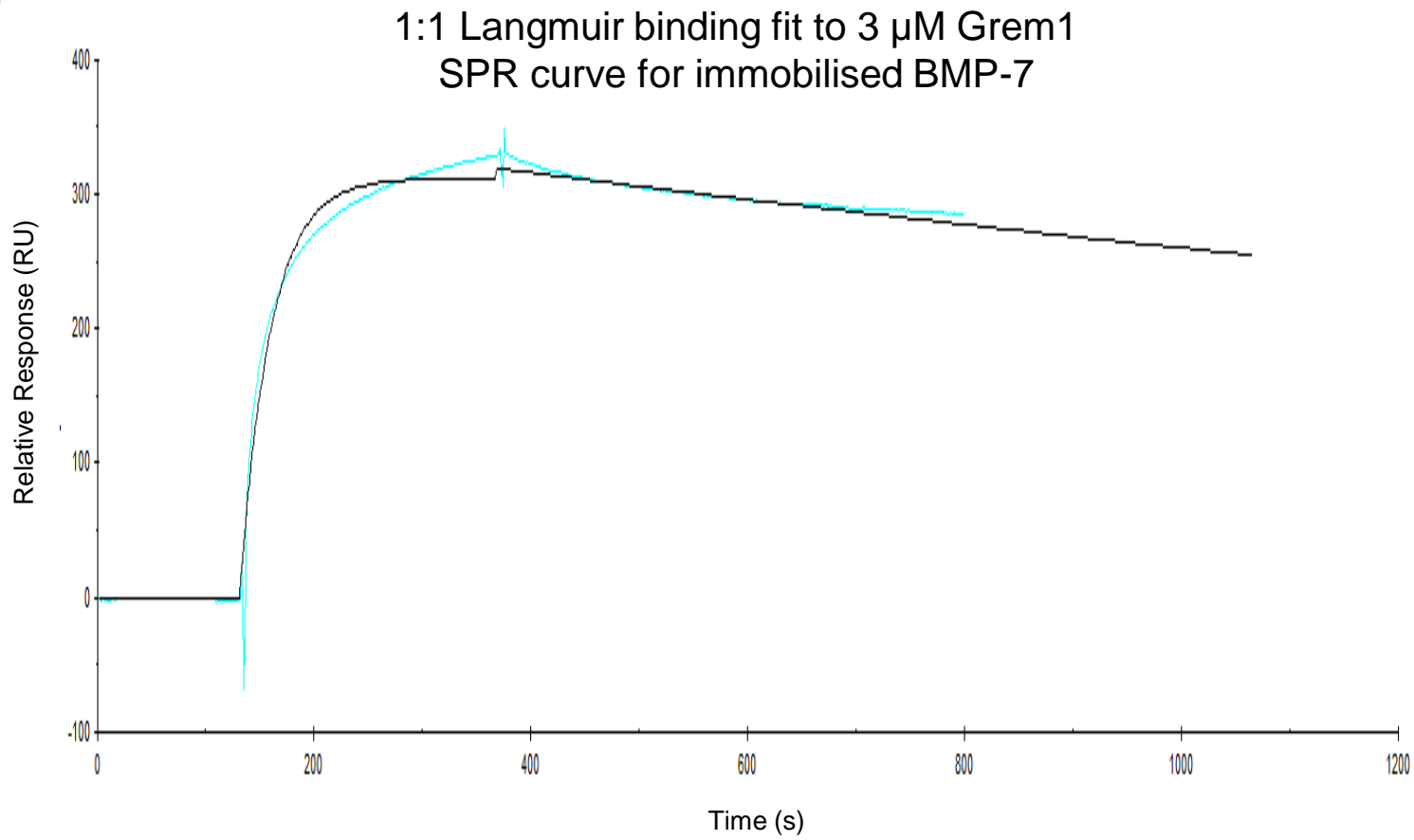


Figure 2.

c.

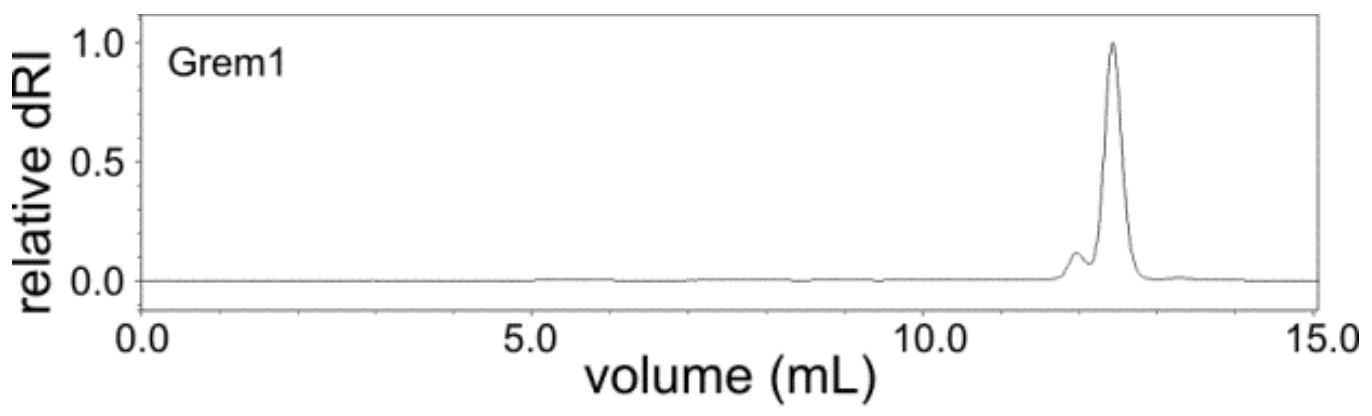

d.

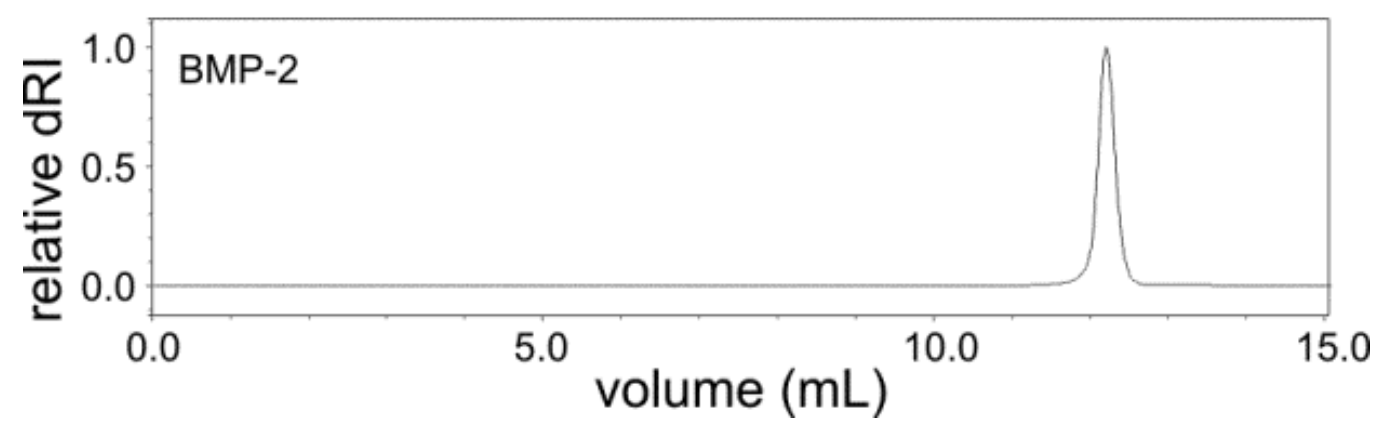

e.

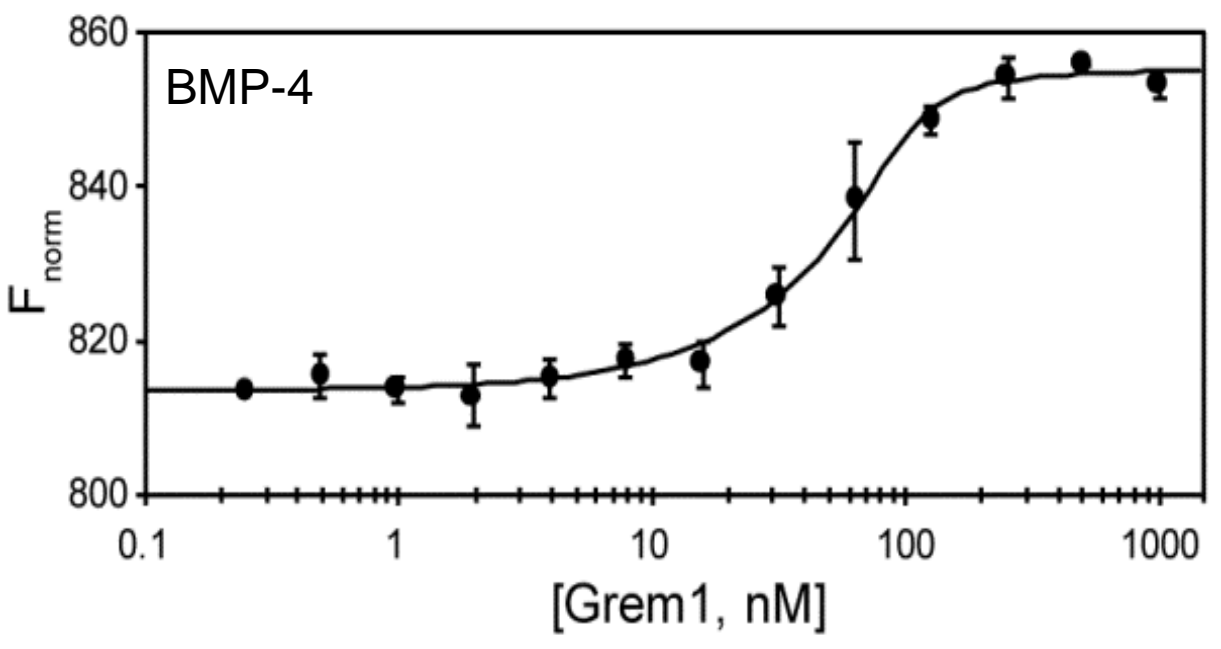


Figure 3.

a. BMP-2 + Vehicle $0.5 \mathrm{ng} / \mathrm{ml} 1 \mathrm{ng} / \mathrm{ml} 2 \underline{2 \mathrm{ng} / \mathrm{ml}} \underline{5 \mathrm{ng} / \mathrm{ml} 10 \mathrm{ng} / \mathrm{ml}}$

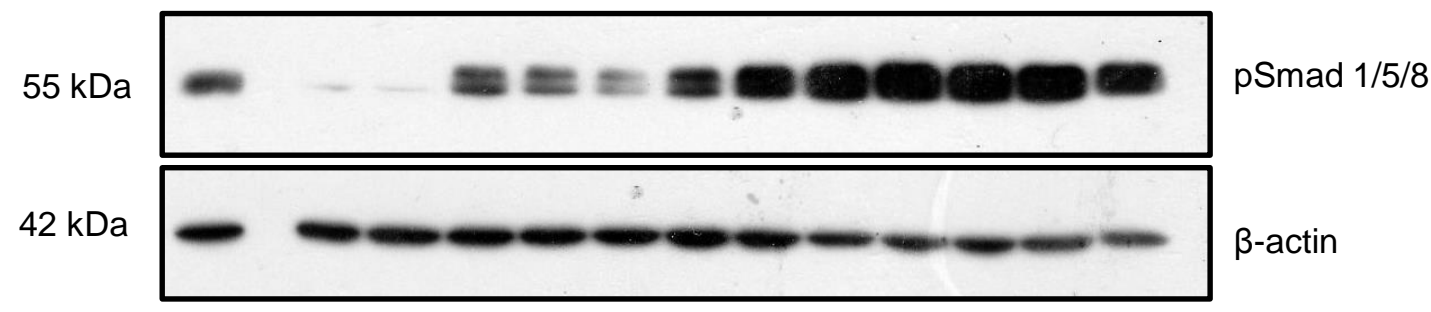

b. BMP-4

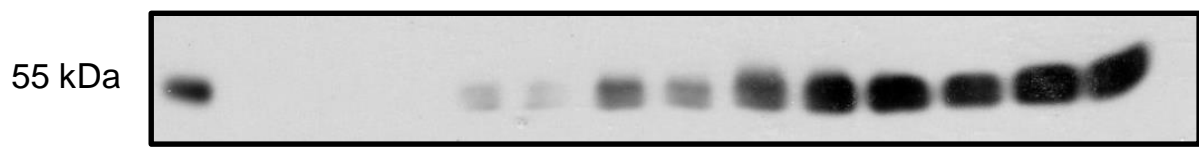

pSmad 1/5/8

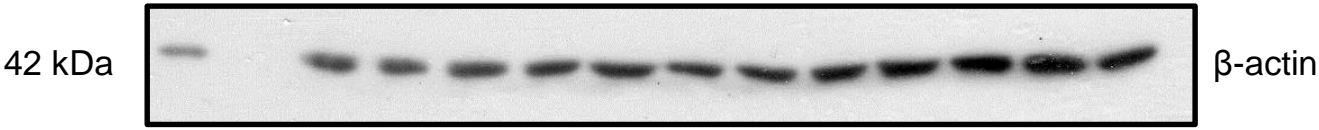

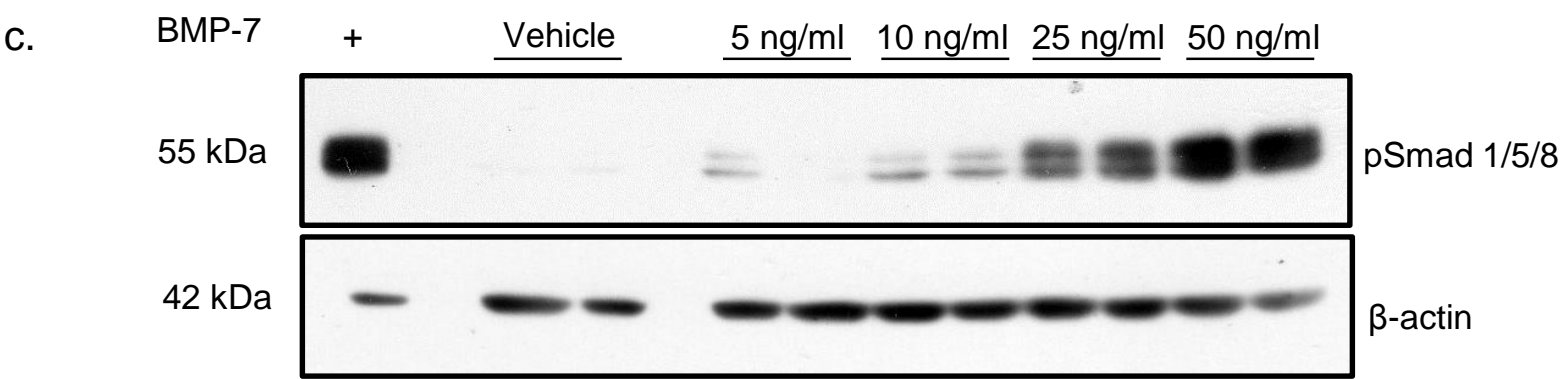

d.

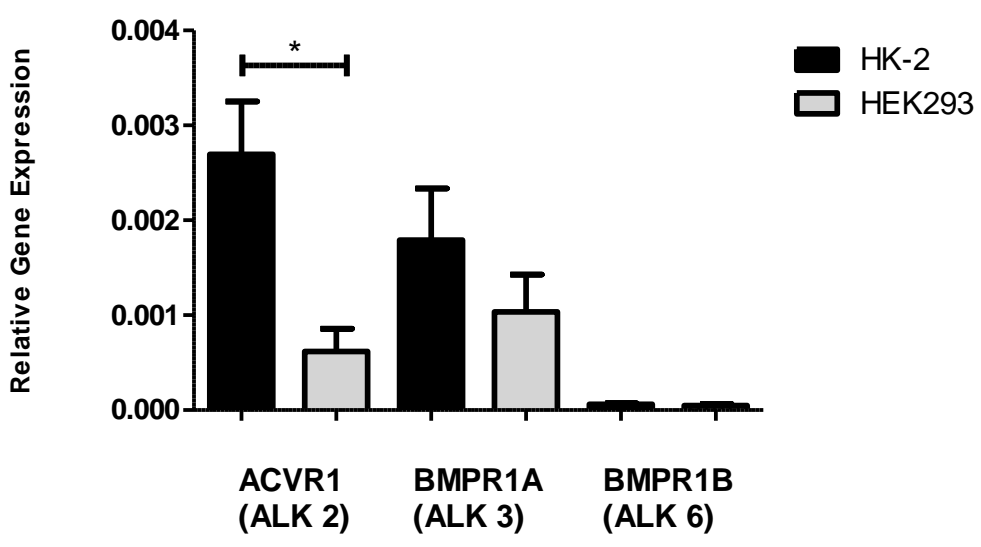


Figure 4.
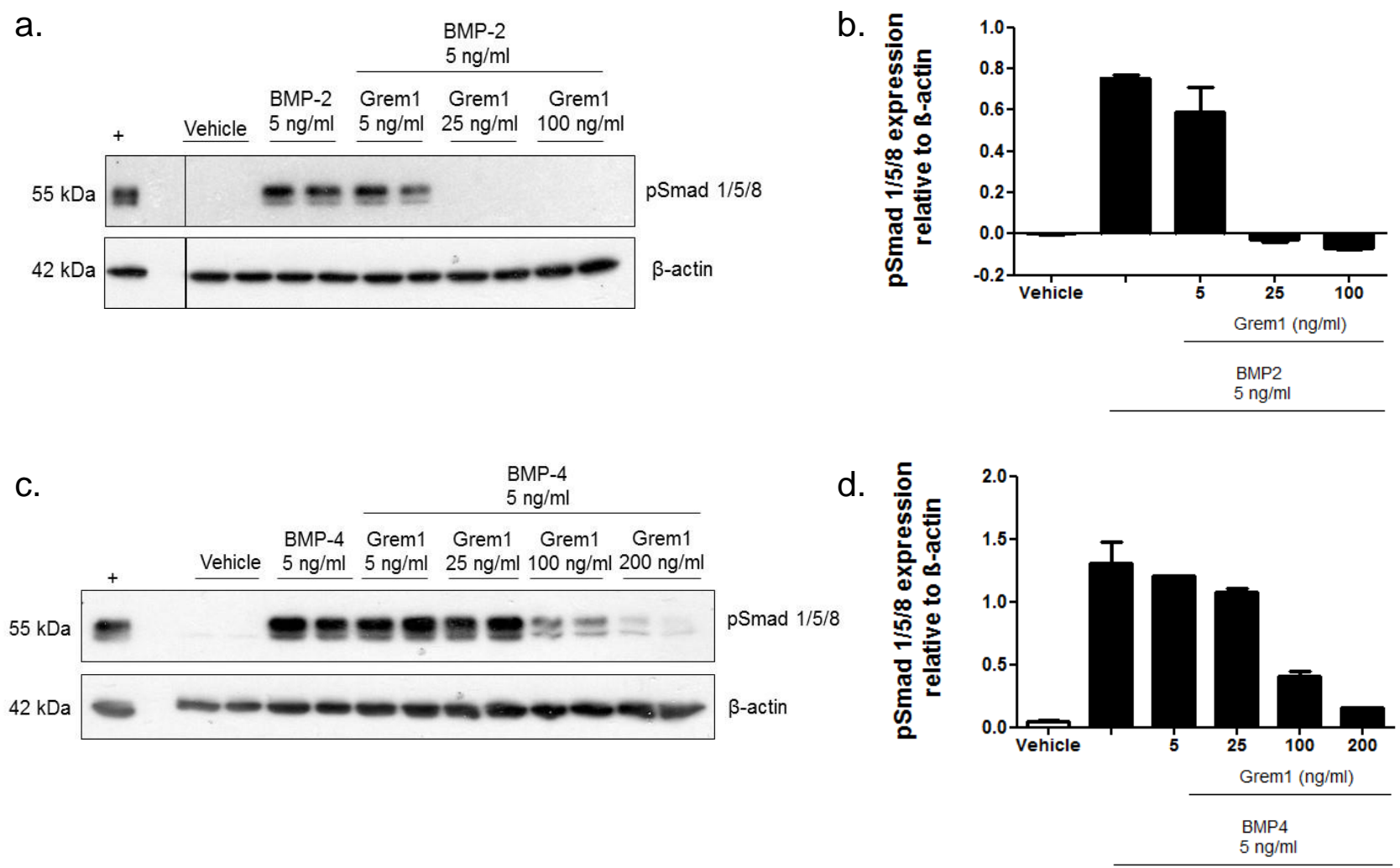

e.
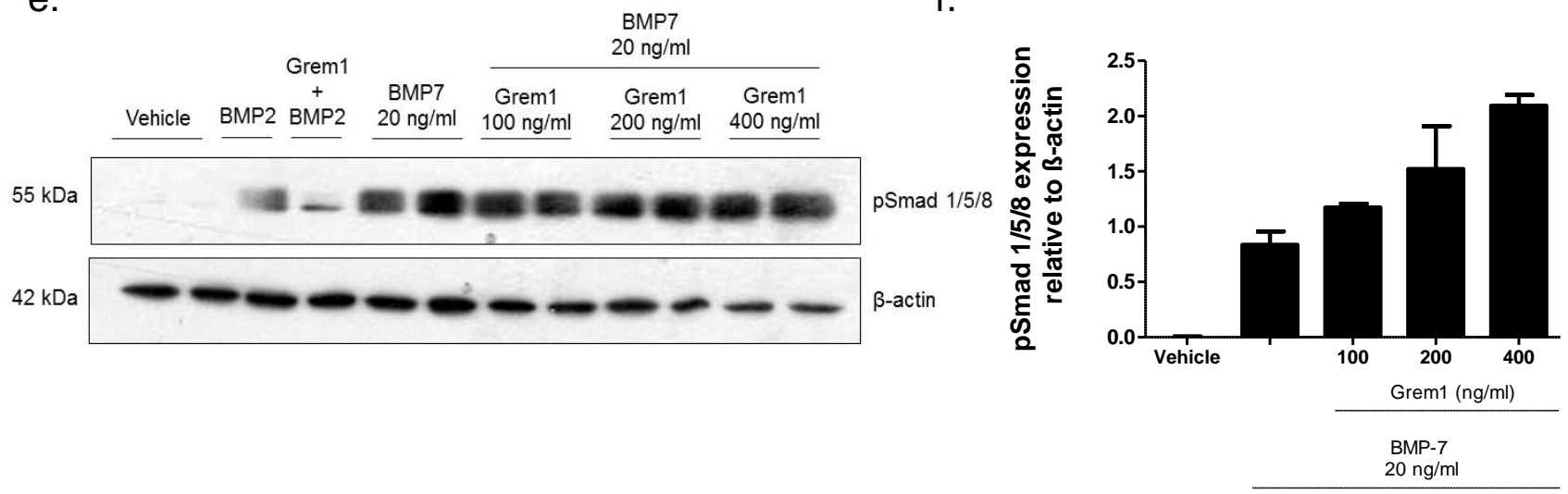
Figure 5.

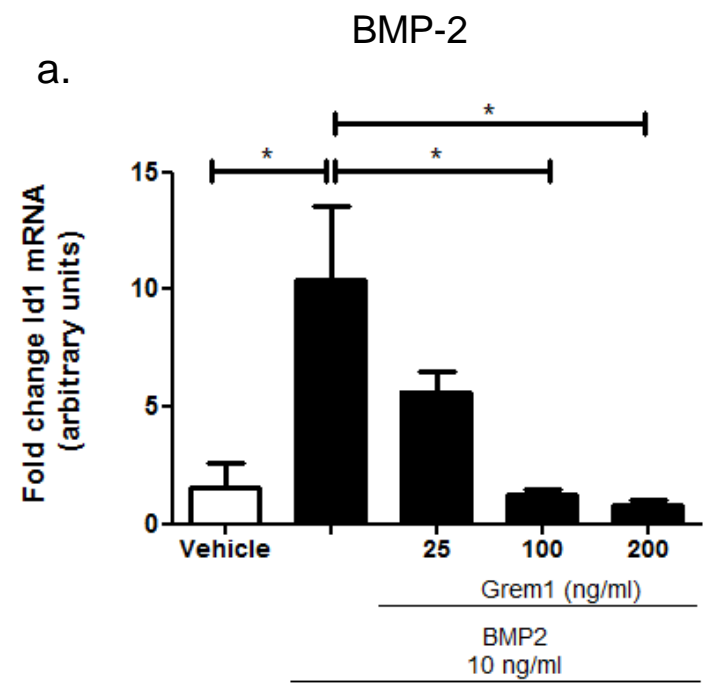
d.
BMP-2

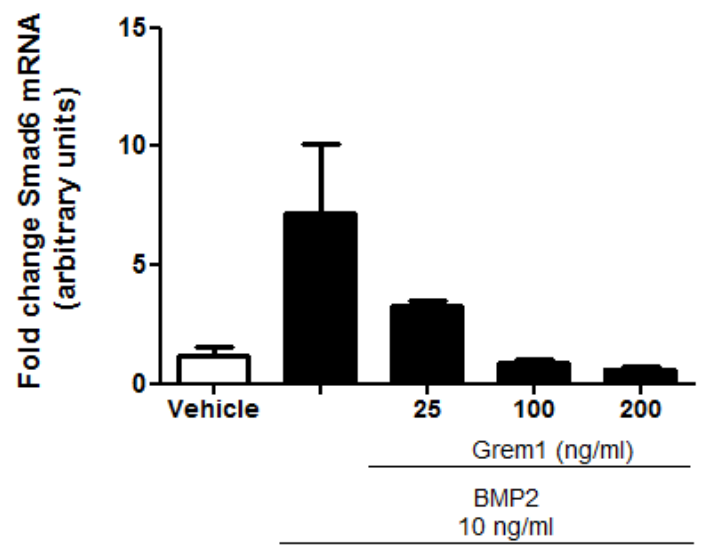

b.

BMP-4

e.

BMP-4

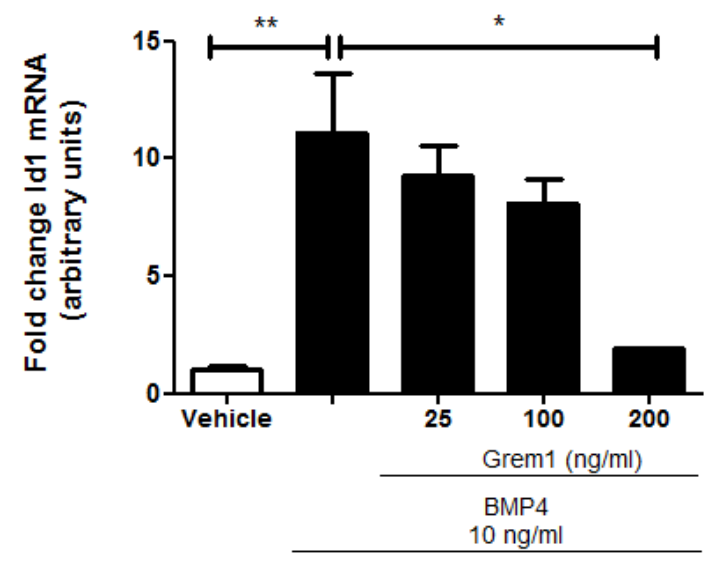

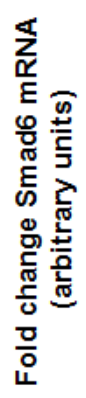

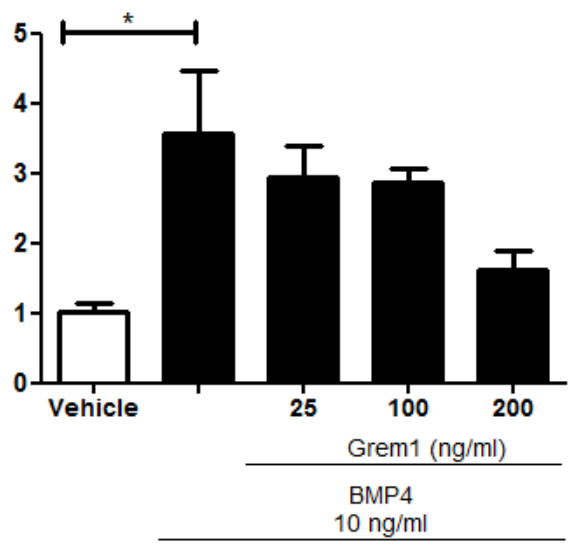

BMP-7

c.

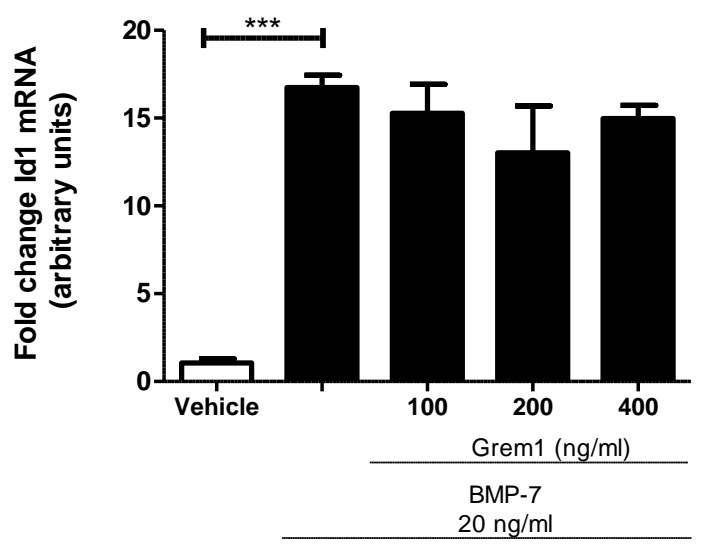

f.

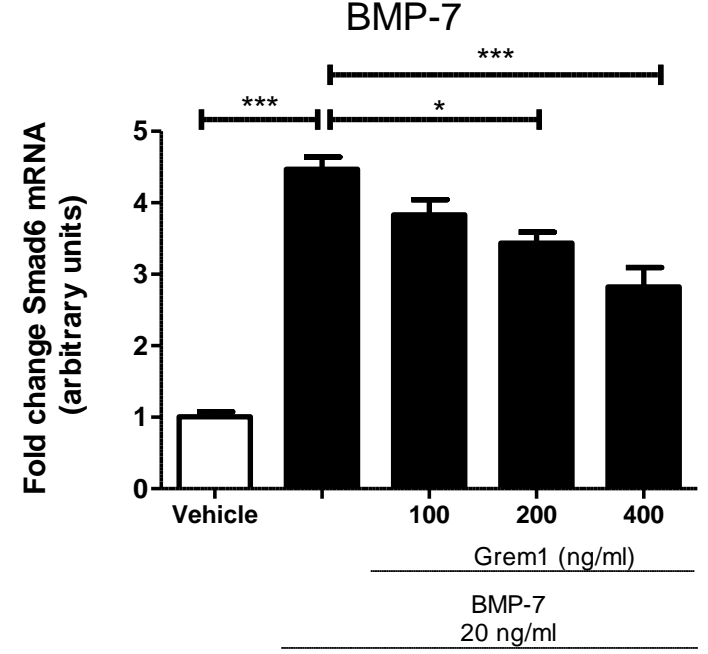


Figure 6.

a.

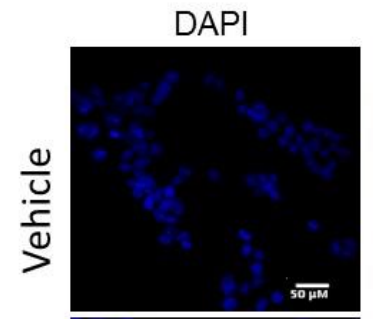

$\sum_{\infty}^{N}$

$\frac{\frac{1}{v}}{\frac{1}{y}}$

$\overline{\text { OलMM }}$
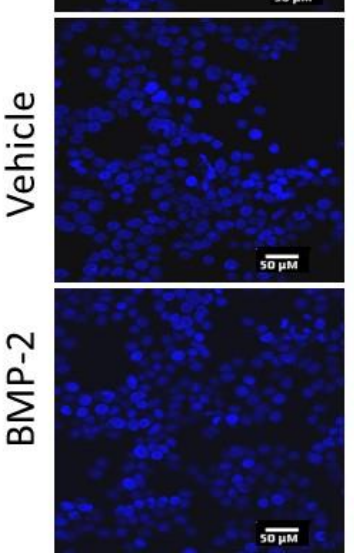

Grem1
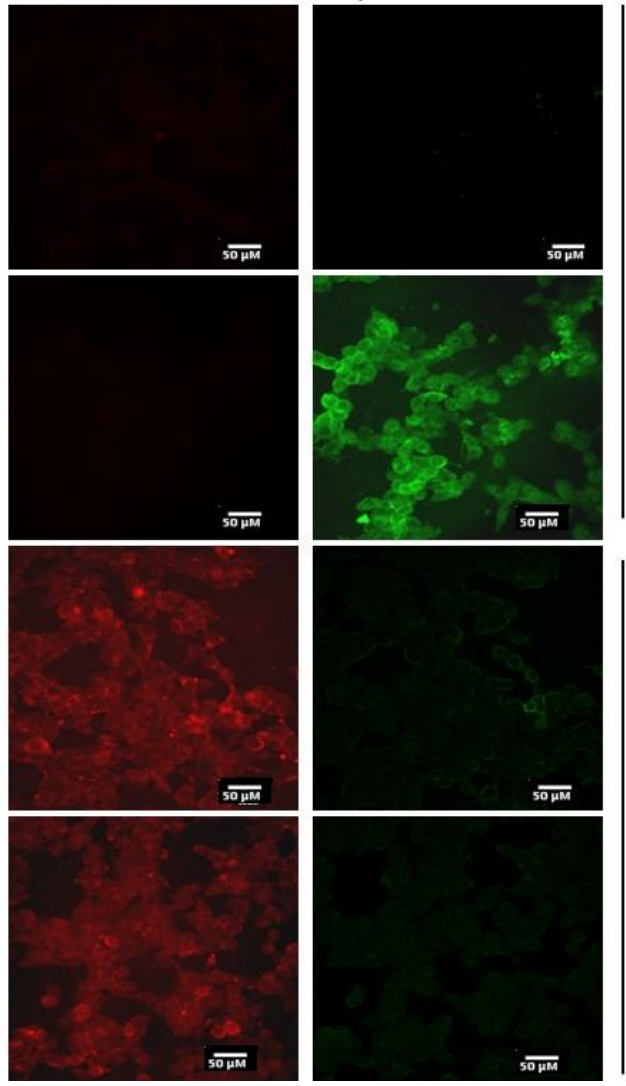

$50 \mathrm{MM}$

pSmad1/5

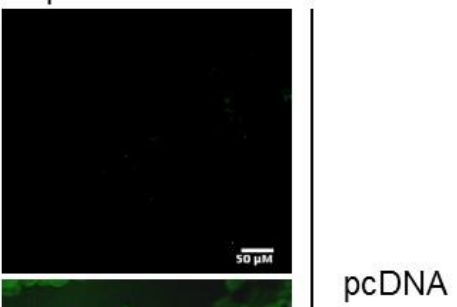

$5 \overline{50 M M}$

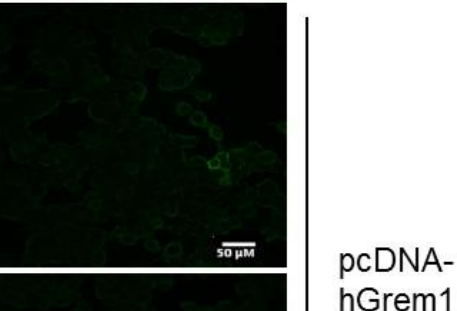

hGrem1

b.

Conditioned

Medium
$+\quad$ pcDNA
pcDNA-hGrem1

$23 \mathrm{kDa}$ 
Figure 7.

a.

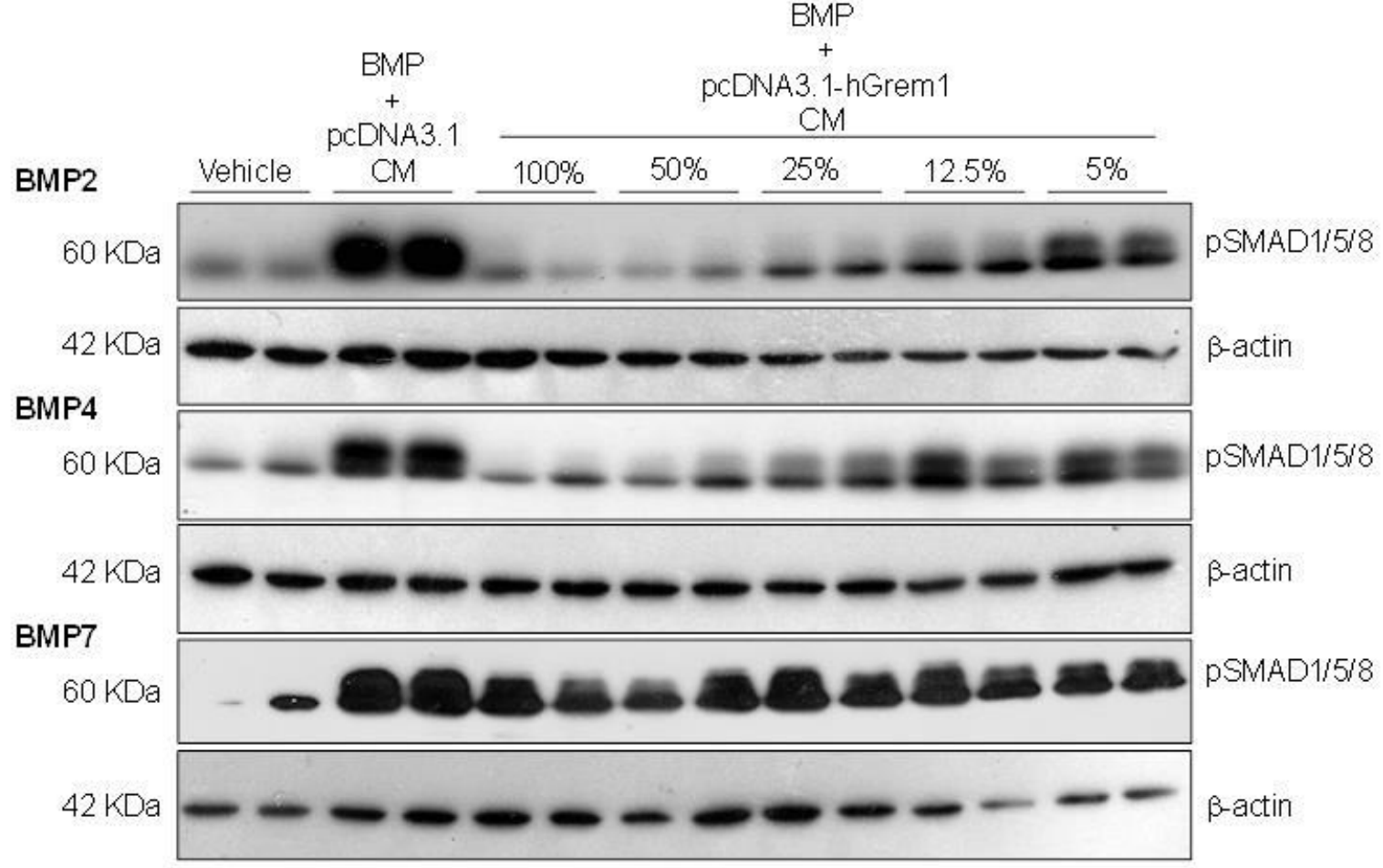

b.

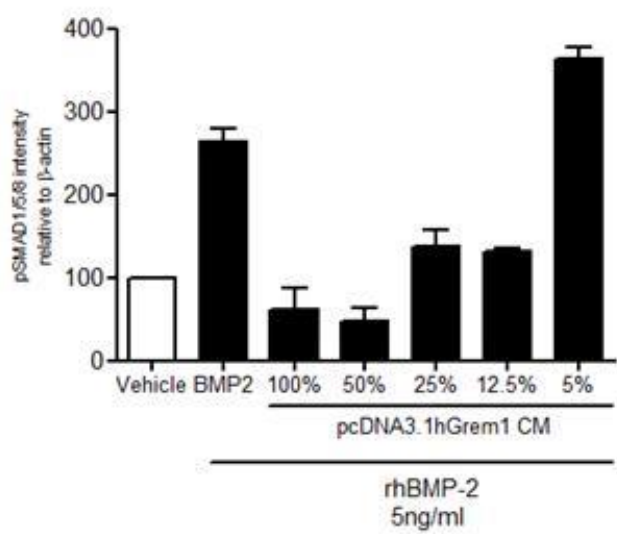

BMP-4

c.

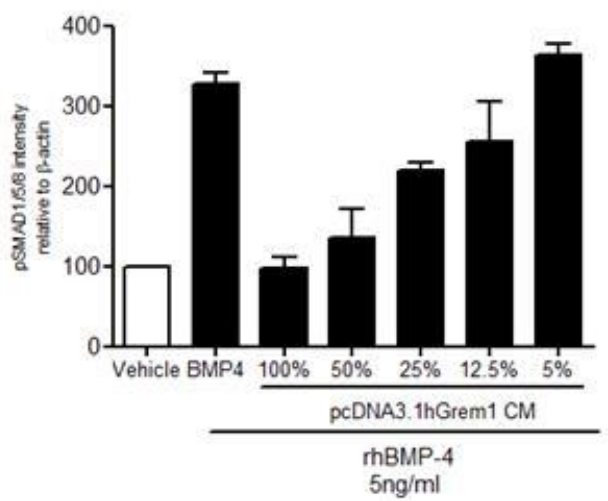

d.

BMP-7

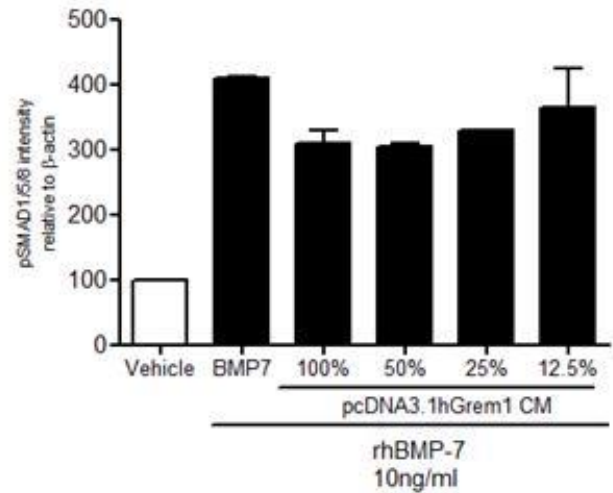


Figure 8.

Co-incubation of BMP-2 and Grem1 in medium

Pre-incubation with Grem1, removal and treatment with BMP-2
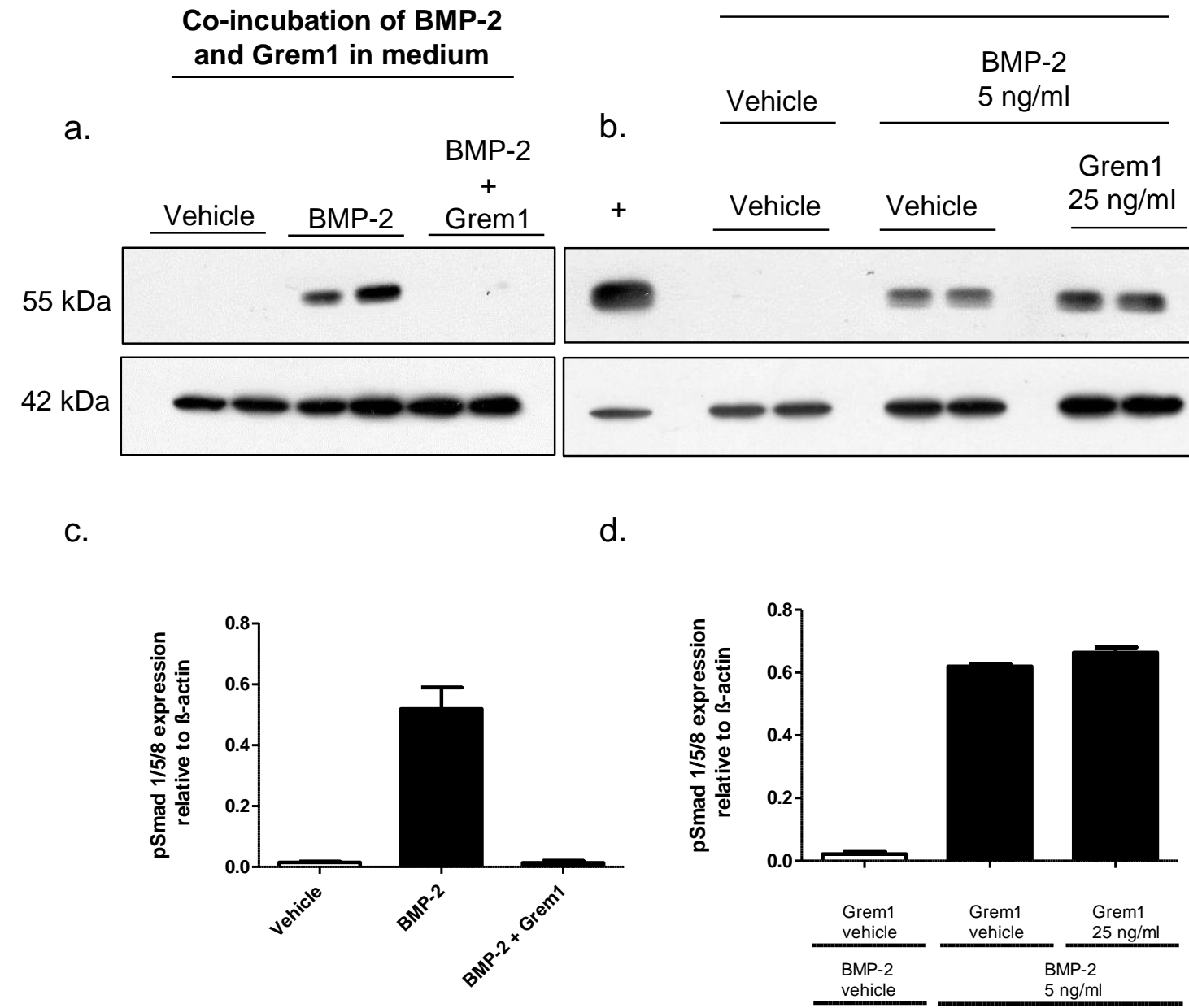